Article

\title{
Sugarcane Bagasse as a Co-Substrate with Oil-Refinery Biological Sludge for Biogas Production Using Batch Mesophilic Anaerobic Co-Digestion Technology: Effect of Carbon/Nitrogen Ratio
}

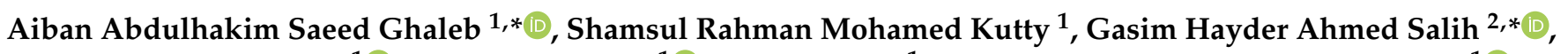 \\ Ahmad Hussaini Jagaba ${ }^{1}$ (D), Azmatullah Noor ${ }^{1}$ (D), Vicky Kumar ${ }^{1}$, Najib Mohammed Yahya Almahbashi ${ }^{1}$ (D), \\ Anwar Ameen Hezam Saeed ${ }^{3}$ (D) and Baker Nasser Saleh Al-dhawi ${ }^{1}$ \\ 1 Department of Civil and Environmental Engineering, Universiti Teknologi PETRONAS, \\ Seri Iskandar 32610, Perak Darul Ridzuan, Malaysia; shamsulrahman@utp.edu.my (S.R.M.K.); \\ ahjagaba@gmail.com (A.H.J.); azmatullah_16005709@utp.edu.my (A.N.); vicky_19000193@utp.edu.my (V.K.); \\ najib_17005375@utp.edu.my (N.M.Y.A.); Baker_18002007@utp.edu.my (B.N.S.A.-d.) \\ 2 Institute of Energy Infrastructure (IEI), Universiti Tenaga Nasional (UNITEN), \\ Kajang 43000, Selangor Darul Ehsan, Malaysia \\ 3 Department of Chemical Engineering, Universiti Teknologi PETRONAS, \\ Seri Iskandar 32610, Perak Darul Ridzuan, Malaysia; anwar_17006829@utp.edu.my \\ * Correspondence: aiban_17004546@utp.edu.my (A.A.S.G.); gasim@uniten.edu.my (G.H.A.S.)
}

check for updates

Citation: Ghaleb, A.A.S.; Kutty, S.R.M.; Salih, G.H.A.; Jagaba, A.H.; Noor, A.; Kumar, V.; Almahbashi, N.M.Y.; Saeed, A.A.H.; Saleh

Al-dhawi, B.N. Sugarcane Bagasse as a Co-Substrate with Oil-Refinery Biological Sludge for Biogas Production Using Batch Mesophilic Anaerobic Co-Digestion Technology: Effect of Carbon/Nitrogen Ratio. Water 2021, 13, 590. https://doi.org/ 10.3390/w13050590

Received: 7 December 2020

Accepted: 16 January 2021

Published: 25 February 2021

Publisher's Note: MDPI stays neutral with regard to jurisdictional claims in published maps and institutional affiliations.

Copyright: (c) 2021 by the authors. Licensee MDPI, Basel, Switzerland. This article is an open access article distributed under the terms and conditions of the Creative Commons Attribution (CC BY) license (https:// creativecommons.org/licenses/by/ $4.0 /)$.

\begin{abstract}
Man-made organic waste leads to the rapid proliferation of pollution around the globe. Effective bio-waste management can help to reduce the adverse effects of organic waste while contributing to the circular economy at the same time. The toxic oily-biological sludge generated from oil refineries' wastewater treatment plants is a potential source for biogas energy recovery via anaerobic digestion. However, the oily-biological sludge's carbon/nitrogen $(\mathrm{C} / \mathrm{N})$ ratio is lower than the ideal 20-30 ratio required by anaerobic digestion technology for biogas production. Sugarcane bagasse can be digested as a high $\mathrm{C} / \mathrm{N}$ co-substrate while the oily-biological sludge acts as a substrate and inoculum to improve biogas production. In this study, the best $\mathrm{C} / \mathrm{N}$ with co-substrate volatile solids (VS)/inoculum VS ratios for the co-digestion process of mixtures were determined empirically through batch experiments at temperatures of $35-37^{\circ} \mathrm{C}, \mathrm{pH}(6-8)$ and $60 \mathrm{rpm}$ mixing. The raw materials were pre-treated mechanically and thermo-chemically to further enhance the digestibility. The best condition for the sugarcane bagasse delignification process was $1 \%(w / v)$ sodium hydroxide, 1:10 solid-liquid ratio, at $100{ }^{\circ} \mathrm{C}$, and $150 \mathrm{rpm}$ for $1 \mathrm{~h}$. The results from a 33-day batch anaerobic digestion experiment indicate that the production of biogas and methane yield were concurrent with the increasing $\mathrm{C} / \mathrm{N}$ and co-substrate VS/inoculum VS ratios. The total biogas yields from $\mathrm{C} / \mathrm{N}$ 20.0 with co-substrate VS/inoculum VS 0.06 and C/N 30.0 with co-substrate VS/inoculum VS 0.18 ratios were 2777.0 and $9268.0 \mathrm{~mL}$, respectively, including a methane yield of 980.0 and $3009.3 \mathrm{~mL}$, respectively. The biogas and methane yield from C/N 30.0 were higher than the biogas and methane yields from C/N 20.0 by 70.04 and $67.44 \%$, respectively. The highest biogas and methane yields corresponded with the highest $\mathrm{C} / \mathrm{N}$ with co-substrate VS/inoculum VS ratios (30.0 and 0.18), being $200.6 \mathrm{~mL} / \mathrm{g} \mathrm{VS}_{\text {removed }}$ and $65.1 \mathrm{~mL} \mathrm{CH}_{4} / \mathrm{g} \mathrm{VS}_{\text {removed, }}$, respectively.
\end{abstract}

Keywords: anaerobic co-digestion; oily-biological sludge; sugarcane bagasse; biogas; hazard waste management; biomethane

\section{Introduction}

Environmental pollution due to rapid waste generation and energy insecurity has become a global challenge in recent years. The combustion of fossil fuels from five sectors, namely energy generation, food and agriculture, transport, industry and economy, and 
households, is considered the primary source of environmental pollution and greenhouse gas emissions [1]. Although the eventual depletion of fossil fuels will significantly reduce greenhouse gas emissions, it will also result in energy insecurity. Therefore, resolving the issues of environmental pollution and energy insecurity gradually through carbon recovery from non-sustainable and sustainable resources is a global concern and of interest for researchers [1-4].

Organic waste generated from industrial activities, such as biological industrial sludge, is toxic because it contains heavy metals and has adverse impacts on humans, the air, soil, and water. In addition to this, it is estimated that globally, around one billion tonnes of agricultural waste are generated annually, and $80 \%$ of this waste is organic $[5,6]$. This organic waste is composed of biodegradable and non-biodegradable portions. The biodegradable portion can be converted into water, methane, and carbon dioxide by microorganisms during aerobic and anaerobic digestion processes as an effective technology for high moisture content sludge compared to other current technologies for energy recovery from the sludge, such as combustion, pyrolysis, and gasification [7-10]. Therefore, non-sustainable organic waste generated from industrial activities, such as biological sludge generated from industrial wastewater effluent treatment systems, can contribute together with sustainable organic waste generated from biomass to energy recovery to reduce environmental pollution and contribute to a gradual transition from non-renewable to renewable energy.

Energy production using anaerobic digestion technology for high-strength waste treatment which is not residential in nature has been applied historically, with proven and valuable outcomes $[11,12]$. Due to the diverse characteristics related to proximate and ultimate analysis of the organic waste and the need for a suitable microorganism environment, such as nutrient balance, $\mathrm{pH}$ temperature and so on, anaerobic co-digestion is an effective way to enhance the digestion process for better biogas quantity and quality [13-15]. The anaerobic co-digestion process can reduce environmental pollution and improve the circular economy through the conversion of low value materials such as organic waste, either agricultural, residential or industrial, to high value materials such as biofuels [16-18].

During the treatment of wastewater in petroleum oil refineries, proper management of toxic organic oily-biological sludge is needed. The anaerobic digestion process is an efficient method to treat organic waste by converting most of the organic matter into biogas. Thus, oily-biological sludge can be digested to produce biogas and reduce its negative impacts on the environment. However, the carbon/nitrogen $(\mathrm{C} / \mathrm{N})$ ratio for oily-biological sludge is low and does not meet the 20-30 ratio requirements of the anaerobic digestion environment [19]. Hence, anaerobic co-digestion with another organic waste that has a high $\mathrm{C} / \mathrm{N}$ ratio is needed. Sugarcane bagasse is a lignocellulosic organic waste that can be treated bio-chemically using anaerobic digestion technology for biogas production [20]. Meanwhile, it has a high $\mathrm{C} / \mathrm{N}$ ratio and is readily available, as 54 million dry tonnes of it are generated annually around the world [21]. Therefore, sugarcane bagasse can be digested as a co-substrate with oily-biological sludge which acts as a substrate and inoculum for biogas production. The objectives of this study were to investigate the effect of $\mathrm{C} / \mathrm{N}$ ratios together with co-substrate volatile solids (VS)/inoculum VS ratios during the anaerobic co-digestion process for pre-treated oily-biological sludge and sugarcane bagasse. To increase the $\mathrm{C} / \mathrm{N}$ ratio, we need to increase the dosage of sugarcane bagasse. Subsequently, the co-substrate VS/inoculum VS ratio will increase. Therefore, the effect on biogas and methane yield is related at the same time to $\mathrm{C} / \mathrm{N}$ and co-substrate VS/inoculum VS ratios. The experiments were carried out under mesophilic conditions, and the raw materials were mechanically and thermo-chemically pre-treated to improve the anaerobic co-digestion process and enhance biogas production.

\section{Materials and Methods}

\subsection{Materials}

Sugarcane bagasse was collected from a night market at Seri Iskandar, Malaysia. The bagasse was first manually cut to an average of $15 \mathrm{~cm}$ and then cleaned using tap water 
to remove any trapped impurities and ligneous. The bagasse was then dried in an oven at $105^{\circ} \mathrm{C}$ for $24 \mathrm{~h}$ to obtain a consistent dry weight. Next, the dried bagasse was ground and milled to smaller than $0.5 \mathrm{~mm}$ using a mechanical shredder machine (Granulator WSGP-230) and miller machine (Puluerisette 16). The grinding and milling of the dried bagasse increased its surface area and digestibility by the bacteria during the anaerobic co-digestion process [22,23].

The dried sugarcane bagasse was treated thermo-chemically using sodium hydroxide in different ratios, temperatures, and periods to reduce lignin content as much as possible, which was recalcitrant to the hydrolysis process [24]. Due to the acidic nature of the sugarcane bagasse, mechanical and alkali-thermal pre-treatment methods were selected as effective methods to enhance the delignification and degradation process for better biogas yield and to increase the $\mathrm{pH}$ to meet the required $\mathrm{pH}$ range for an anaerobic digestion process, between 6 and 8 [19,25-27]. The thermo-chemical pre-treatment ratios were $1 \%$ and $2 \%(w / v) \mathrm{NaOH}$ for 45,60 , and $75 \mathrm{~min}$. The solid/liquid ratio was 1:10, the temperature was $100{ }^{\circ} \mathrm{C}$, and the rpm was $150 \mathrm{rpm}$.

The oily-biological sludge is a waste-activated sludge that was collected from a petroleum oil refinery wastewater effluent treatment system and stored in a cooling room below $4{ }^{\circ} \mathrm{C}$ for less than $24 \mathrm{~h}$ before proceeding with the co-digestion process. Pre-treatment for the sludge was needed to enhance the degradation of the organic matter [28]. Due to the acidic nature of the oily-biological sludge, the alkali-thermal pre-treatment method was selected as an effective method to enhance the degradation process for better biogas yield and to increase the $\mathrm{pH}$ to meet the required $\mathrm{pH}$ range for the anaerobic digestion process, between 6 and $8[19,29,30]$. The sludge was thermo-chemically pre-treated using sodium hydroxide $1 \mathrm{~g} / \mathrm{L}$, at $100{ }^{\circ} \mathrm{C}, 150 \mathrm{rpm}$ for $1 \mathrm{~h}$ to increase its $\mathrm{pH}$ as it has an acidic nature to comply with the required range of $\mathrm{pH}$ during anaerobic digestion process, between 6-8.

\subsection{Analytical Methods, Design and Operational Setup}

Proximate analysis for the treated oily-biological sludge (TOBS) was conducted according to the American Public Health Association (APHA), 1998 methods to determine the total solids (TS) and volatile solids (VS). The ultimate analysis was conducted to determine the carbon, hydrogen, nitrogen, and sulfur (CHNS) elements using the CHNS elementar machine (Vario MICRO) to design the mixing ratios according to the $\mathrm{C} / \mathrm{N}$ ratio for the batch experiments.

The proximate analysis for the treated sugarcane bagasse was performed in accordance with the American Society for Testing and Materials (ASTM) D3172-89 standard. The $\mathrm{pH}$ of the sugarcane bagasse was determined according to Hach method. The ultimate analysis was performed according to ASTM D5373 standard using the same elementar machine to determine the $\mathrm{C} / \mathrm{N}$ ratio for the mixtures design. The chemical composition to determine hemicellulose, cellulose and lignin was measured according to Chesson's method to compare and analyse the effect of thermo-chemical pre-treatment method on lignin content.

The functional groups present in the raw and treated sugarcane bagasse were determined by Fourier transform infrared (FTIR) analysis. FTIR analysis was conducted to investigate the effects of thermo-chemical pre-treatment on the functional groups, namely hemicellulose, cellulose, and lignin, using a PerkinElmer analyzer.

Supra 55 VP (Carl-Zeiss AG, Oberkochen, Germany) was used to analyse the surface morphology of raw sugarcane bagasse (RSCB), treated sugarcane bagasse (TSCB), raw oily-biological sludge (ROBS), and treated oily-biological sludge (TOBS) using a variable pressure scanning electron microscope. The images were taken for both materials before and after the thermo-chemical pre-treatment at different magnifications to observe and analyse the effects of the pre-treatment method. The design of mixtures was conducted 
according to the following equation [31], in order to achieve mixtures for both materials between 20 and 30 .

$$
R=\frac{Q_{1}\left(C_{1} *\left(100-M_{1}\right)+Q_{2}\left(C_{2} *\left(100-M_{2}\right)\right.\right.}{Q_{1}\left(N_{1} *\left(100-M_{1}\right)+Q_{2}\left(N_{2} *\left(100-M_{2}\right)\right.\right.}
$$

where:

$R=\mathrm{C} / \mathrm{N}$ ratio;

$Q_{1}, Q_{2}=$ mass of materials "as is" or wet weight;

$C_{1}, C_{2}=$ carbon content of materials (\%);

$N_{1}, N_{2}=$ nitrogen content of materials (\%);

$M_{1}, M_{2}=$ moisture content of materials.

The SOLTEQ TR37 sludge anaerobic digester was used to carry out this study [32]. The size of the digester used for this study was $2.5 \mathrm{~L}$, with a working volume of $2 \mathrm{~L}$. The digester's temperature was set manually using the digester control panel at $35.0-37.0 \pm 0.5^{\circ} \mathrm{C}$, with a mixing speed of $60 \mathrm{rpm}$ for 33 days. The produced biogas was measured every day using a water displacement method, and the content was measured every three days using the German Optima 7 biogas analyzer. The one-way ANOVA test using Microsoft Excel 2010 was used to compare the biogas and methane yield from different reactor groups based on the $\mathrm{C} / \mathrm{N}$ ratio and co-substrate VS/inoculum VS increments. The central point $\mathrm{C} / \mathrm{N}$ ratio mixture was repeated four times to verify the experiment's design. In addition, validation for the maximum biogas and methane yield was carried out using 3 replications for the best ratios.

\section{Results and Discussion}

\subsection{Pre-Treatment Process Analysis, Characterization and Experimental Design}

3.1.1. Thermo-Chemical Pre-Treatment of Raw Sugarcane Bagasse (RSCB)

After mechanical pre-treatment of RSCB was carried out to below a $0.5 \mathrm{~mm}$ particle size, thermo-chemical pre-treatment was conducted using sodium hydroxide to minimize the lignin content and enhance biogas production. Sodium hydroxide was used in different ratios and periods. The hemicellulose, cellulose, and lignin contents before and after the pre-treatment are tabulated in Table 1 . The results show that $1 \%$ sodium hydroxide at $100{ }^{\circ} \mathrm{C}$ and $150 \mathrm{rpm}$ for $1 \mathrm{~h}$ was the best combination pre-treatment to minimize the lignin content from sugarcane bagasse. The lignin content decreased to $13.50 \%$, while the cellulose content increased to $62.05 \%$. This will enhance the hydrolysis process and provide a good source of a digestible, accessible fraction for the microorganisms, which is the cellulose portion $[24,25]$. Three replicates for the best pre-treatment ratio were conducted and the average hemicellulose, cellulose, and lignin contents were $10.55,62.45$ and $13.60 \%$, respectively, with the significance level being more than $95 \%$. Therefore, this ratio was selected for the ultimate and proximate analysis of TSCB, and consequently for the batch design mixtures. Scanning electron microscopy (SEM) and FTIR were used to show the effect of the pre-treatment through surface morphology and functional group changes.

Table 1. Results of delignification process for raw sugarcane bagasse (RSCB) at a temperature of $100{ }^{\circ} \mathrm{C}$ and stirring speed of $150 \mathrm{rpm}$.

\begin{tabular}{cccc}
\hline & Hemicellulose (\%) & Cellulose (\%) & Lignin (\%) \\
\hline RSCB & 24.32 & 36.20 & 28.03 \\
TSCB 1\%, 45 min & 8.03 & 50.40 & 25.30 \\
TSCB 1\%, 60 min & 10.25 & 62.05 & 13.50 \\
TSCB 1\%, 75 min & 8.17 & 58.17 & 16.43 \\
TSCB 2\%, 45 min & 8.37 & 56.80 & 17.87 \\
TSCB 2\%, 60 min & 7.90 & 51.70 & 23.40 \\
TSCB 2\%, 75 min & 4.95 & 64.35 & 14.45 \\
\hline
\end{tabular}


3.1.2. Proximate and Ultimate Analysis for Treated Oily-Biological Sludge (TOBS) and Treated Sugarcane Bagasse (TSCB)

According to Table 2, the $\mathrm{pH}$ for TOBS and TSCB has a base nature induced by chemical pre-treatment using $\mathrm{NaOH}$. This will provide a $\mathrm{pH}$ of 6.2 to 8 , as recommended for an effective anaerobic co-digestion process; during anaerobic co-digestion, the acetogenesis phase has an acidic nature, and that will balance the base nature of the mixtures to be within the recommend $\mathrm{pH}$ range $[19,33]$. The VS for both materials comprise a high portion of the total solids, and this is a good indicator for high biogas yield, as most of the volatile matter will be converted to gas.

Table 2. The main ultimate and proximate analysis of treated oily-biological sludge (TOBS) and treated dry sugarcane bagasse.

\begin{tabular}{ccccc}
\hline Parameter & Unit & TOBS & Unit & TSCB \\
\hline Moisture & $\%$ & 94.20 & $\%$ & 0 \\
Content & N/A & 8.70 & N/A & 7.21 \\
$\mathrm{pH}$ & $\mathrm{g} / \mathrm{L}$ & 58.00 & $\%$ & 100 \\
$\mathrm{TS}$ & $\mathrm{g} / \mathrm{L}$ & 50.46 & $\%$ & 87.80 \\
$\mathrm{VS}$ & \% of TS & 4.31 & $\%$ & 34.70 \\
$\mathrm{C}$ & \% of TS & 0.30 & $\%$ & 0.26 \\
$\mathrm{~N}$ & $\mathrm{~N} / \mathrm{A}$ & 14.42 & $\mathrm{~N} / \mathrm{A}$ & 132.69 \\
$\mathrm{C} / \mathrm{N}$ & & & &
\end{tabular}

From Table 2, the C/N ratio for TOBS and TSCB was found to be 14.42 and 132.692, respectively, at base. The high $\mathrm{C} / \mathrm{N}$ ratio for TSCB will balance the low $\mathrm{C} / \mathrm{N}$ ratio of TOBS to provide a proper environment for microorganisms, with a $\mathrm{C} / \mathrm{N}$ ratio between 20 and 30. These analyses were used in the study of methane modelling through surface response methodology for the anaerobic co-digestion of both materials [32,34].

\subsubsection{FTIR Analysis for Raw Sugarcane Bagasse (RSCB) and Treated Sugarcane Bagasse (TSCB)}

This analysis was conducted to determine the functional groups of RSCB and TSCB to analyse the changes induced by thermo-chemical pre-treatment. Figure $1 \mathrm{a}, \mathrm{b}$ show the FTIR spectra for RSCB and TSCB, respectively. The variation bonds given by the FTIR spectra for the RSCB are shown in Table 3. The variation bonds mainly corresponded to cellulose, hemicellulose, and lignin. Figure 1 a shows a strong peak at $3405.76 \mathrm{~cm}^{-1}$; this indicates the presence of the $\mathrm{O}-\mathrm{H}$ stretching and $\mathrm{NH}$ group. The $\mathrm{OH}$ is related to polyphenol and alcohol, which was present in cellulose and lignin [35]. The peak at $2918.97 \mathrm{~cm}^{-1}$ reflects the $\mathrm{C}-\mathrm{H}$ stretching, indicating the presence of methylene in the cellulose and hemicellulose [36,37]. The peak at $1733.42 \mathrm{~cm}^{-1}$ reflects the $\mathrm{C}=\mathrm{O}$ stretching of acetal groups available in hemicellulose [38]. The peak at $1633.70 \mathrm{~cm}^{-1}$ reflects the $\mathrm{C}=\mathrm{O}$ stretching group carbonyl of ketonic groups found in lignin [37]. The peaks at 1605.30 and $1513.89 \mathrm{~cm}^{-1}$ represent the aromatic skeleton $\mathrm{C}=\mathrm{C}$ available in lignin [39-41]. The peaks at 1427.82 and $1375.33 \mathrm{~cm}^{-1}$ signify the $\mathrm{CH} 2$ asymmetric stretching and $\mathrm{C}-\mathrm{H}$ bend available in lignin and cellulose, respectively [42,43]. The peaks at 1249.50 and $1162.91 \mathrm{~cm}^{-1}$ describe the C-O stretching and C-O-C asymmetrical stretching available in hemicellulose and cellulose, respectively $[38,40]$. Finally, the peak at $1052 \mathrm{~cm}^{-1}$ may be due to the $\mathrm{C}-\mathrm{O}$ stretching group available in cellulose [44].

The variation bonds given by the FTIR spectra for the TSCB are tabulated in Table 4. The strong peak at $3432.35 \mathrm{~cm}^{-1}$, as shown in Figure $1 \mathrm{~b}$, indicates that the $\mathrm{O}-\mathrm{H}$ stretching and $\mathrm{NH}$ group, and the $\mathrm{OH}$ is related to the polyphenol and alcohol present in the cellulose and lignin [35]. The peak at $2912.80 \mathrm{~cm}^{-1}$ reflects the C-H stretching found in methylene, which is present in the cellulose and hemicellulose [36,37]. The peak at $1600.03 \mathrm{~cm}^{-1}$ reflects the C-H skeletal variation available in lignin [34]. The peak at $1421.81 \mathrm{~cm}^{-1}$ presents the $\mathrm{C}-\mathrm{H}$ bending present in cellulose [45]. Finally, the peaks at 1163.45 and $1057.39 \mathrm{~cm}^{-1}$ 
indicate the C-O-C asymmetrical stretching and C-O stretching available in cellulose and hemicellulose $[38,44,46]$. The FTIR spectra analysis for RSCB and TSCB proved that the thermo-chemical pre-treatment for the RSCB induced a positive effect in the chemical structure, where TSCB had a lower lignin content compared to RSCB. Therefore, the thermo-chemical pre-treatment for the RSCB was successful in reducing the lignin content, which inhibited the anaerobic co-digestion process. The TSCB also enhanced the biogas production as the major fraction contents were cellulose and hemicellulose, which were the primary sources for the microorganism activities during the anaerobic co-digestion process with oily-biological sludge.
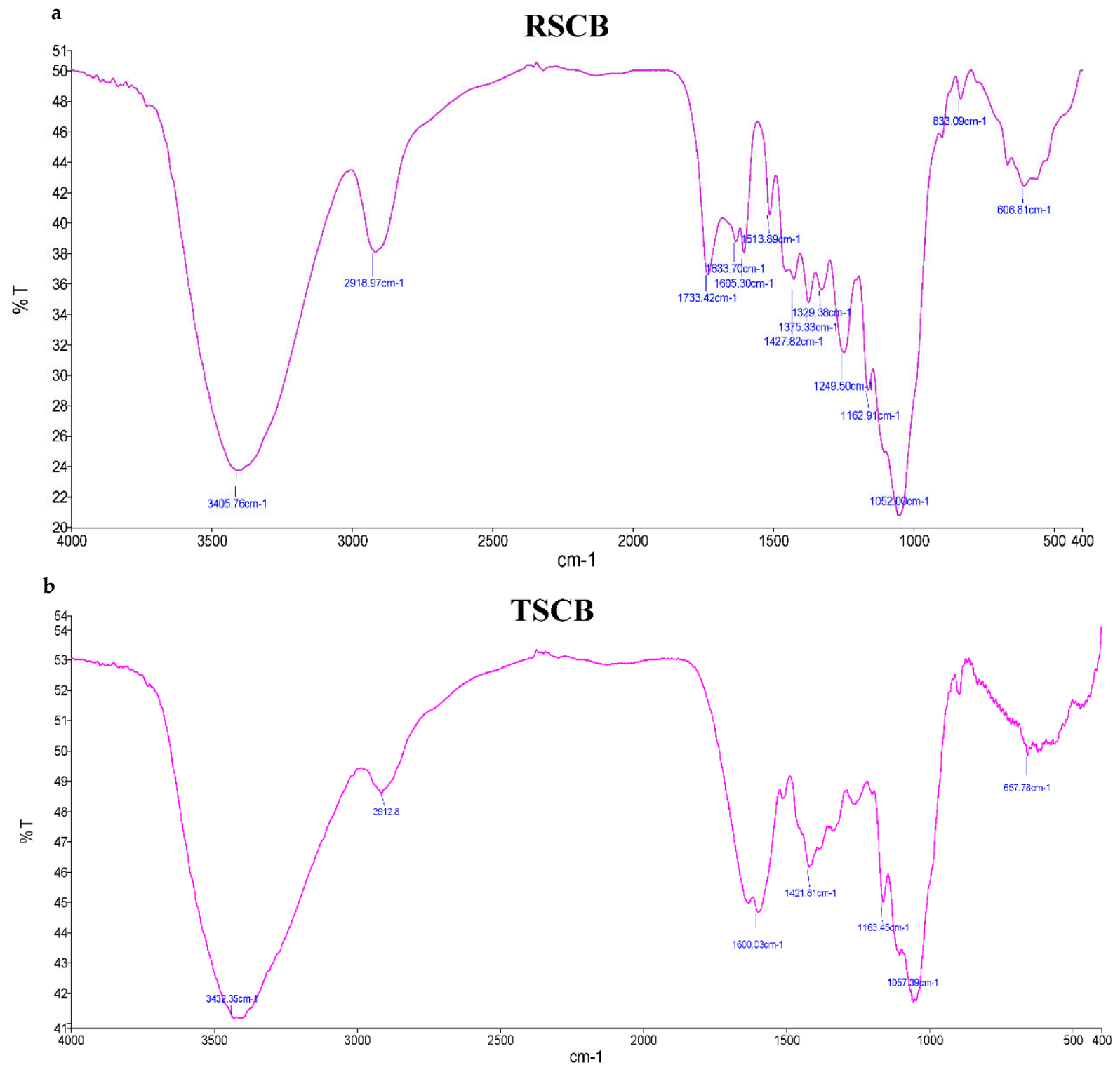

Figure 1. (a) FTIR spectrum of RSCB (b) FTIR spectrum of treated sugarcane bagasse (TSCB). 
Table 3. FTIR characteristics of RSCB.

\begin{tabular}{ccc}
\hline Bagasse & Frequency $\left(\mathbf{c m}^{-\mathbf{1}}\right)$ & Possible Assignment \\
\hline 3405.76 & O-H Stretching and NH group (cellulose and lignin) \\
2918.97 & C-H Stretching (cellulose and hemicellulose) \\
1733.42 & C=O stretching (Hemicellulose) \\
1633.70 & C=O stretching (lignin) \\
1605.30 & Aromatic skeleton C=C (lignin) \\
1513.89 & Aromatic skeleton C=C (lignin) \\
1427.82 & CH2 asymmetric stretching (lignin) \\
1375.33 & C-H bend (cellulose) \\
1329.38 & C-F stretch \\
1249.50 & C-O stretching (hemicellulose) \\
RSCB & 1162.91 & hemicellulose) \\
& 1052.00 & C-O-C Asymmetrical stretching (cellulose and \\
& 833.09 & C-O stretching (cellulose) \\
606.81 & C-Br bending \\
& &
\end{tabular}

Table 4. FTIR characteristics of TSCB.

\begin{tabular}{|c|c|c|}
\hline Bagasse & Frequency $\left(\mathrm{cm}^{-1}\right)$ & Possible Assignment \\
\hline \multirow{7}{*}{ TSCB } & 3432.35 & O-H Stretching and $\mathrm{NH}$ (cellulose and lignin) \\
\hline & 2912.80 & C-H Stretching (cellulose and hemicellulose) \\
\hline & 1600.03 & Aromatic skeletal C=C (lignin) \\
\hline & 1421.81 & C-H bending (cellulose) \\
\hline & 1163.45 & $\begin{array}{l}\text { C-O-C asymmetrical stretching } \\
\text { (cellulose and hemicellulose) }\end{array}$ \\
\hline & 1057.39 & C-O stretching (cellulose) \\
\hline & 657.78 & $\equiv \mathrm{C}-\mathrm{H}$ bend \\
\hline
\end{tabular}

3.1.4. Surface Morphology of Raw Sugarcane Bagasse (RSCB) and Treated Sugarcane Bagasse (TSCB)

The SEM observations for the RSCB and TSCB depicted in Figures 2 and 3 show an apparent physical change in the inner and outer surface induced by the thermo-chemical pre-treatment method. Figure 2a shows the general view for RSCB. There are two structures indicated by arrows $\mathrm{S}$ and $\mathrm{P}$.

The arrow $S$ indicates the fiber structure for the outer surface of the RSCB, which is usually the lignin portion. In contrast, the arrow $\mathrm{P}$ indicates the pith structure of the RSCB, which is the cellulose and hemicellulose fraction. Figure $2 b$ shows that the TSCB also had two structures, indicated by the arrow $S$ for fiber and $\mathrm{P}$ for pith. Based on Figure 2a,b, it was evident that RSCB had a higher fiber structure portion compared to TSCB, which indicated that the thermo-chemical pre-treatment method had a significant effect in reducing the lignin content.

The fiber structure of RSCB was more structured and attached compared to TSCB, which was independent and partially unattached. This indicates that the thermo-chemical pre-treatments broken down the bonds of lignin content at the outer surface, and reduced the inhabitation effect of the low unstructured lignin content during the anaerobic codigestion process. Apart from that, it also increased the accessibility to the cellulose fraction during the hydrolysis process by bacteria [47].

Figure 3c,d show the magnification of pith structures for RSCB and TSCB. It is apparent that the pith structure of TSCB was more fragile and fragmented compared to the pith structure of RSCB. This indicates that the thermal pre-treatment also affected the pith structure, and a portion of the hemicellulose fraction was removed during the pre-treatment process which led to small pores, as shown in Figure 3d. 

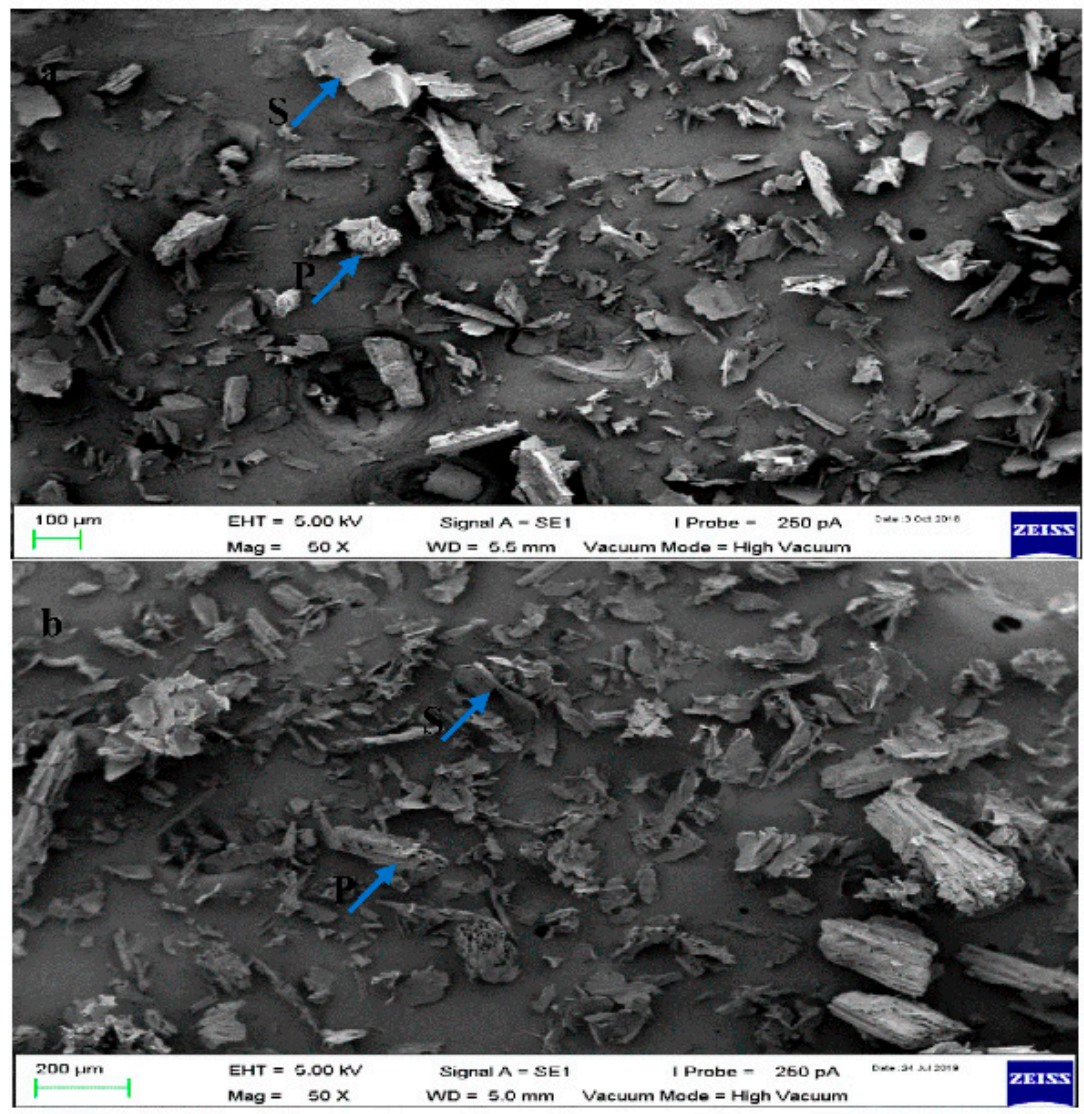

Figure 2. (a) General view of the RSCB sample shows the fibers (outer surface) and pith (inner surface), (arrows S and P). (b) General view of the TSCB sample shows the fibers (outer surface) and pith (inner surface), (arrows $S$ and $P$ ).
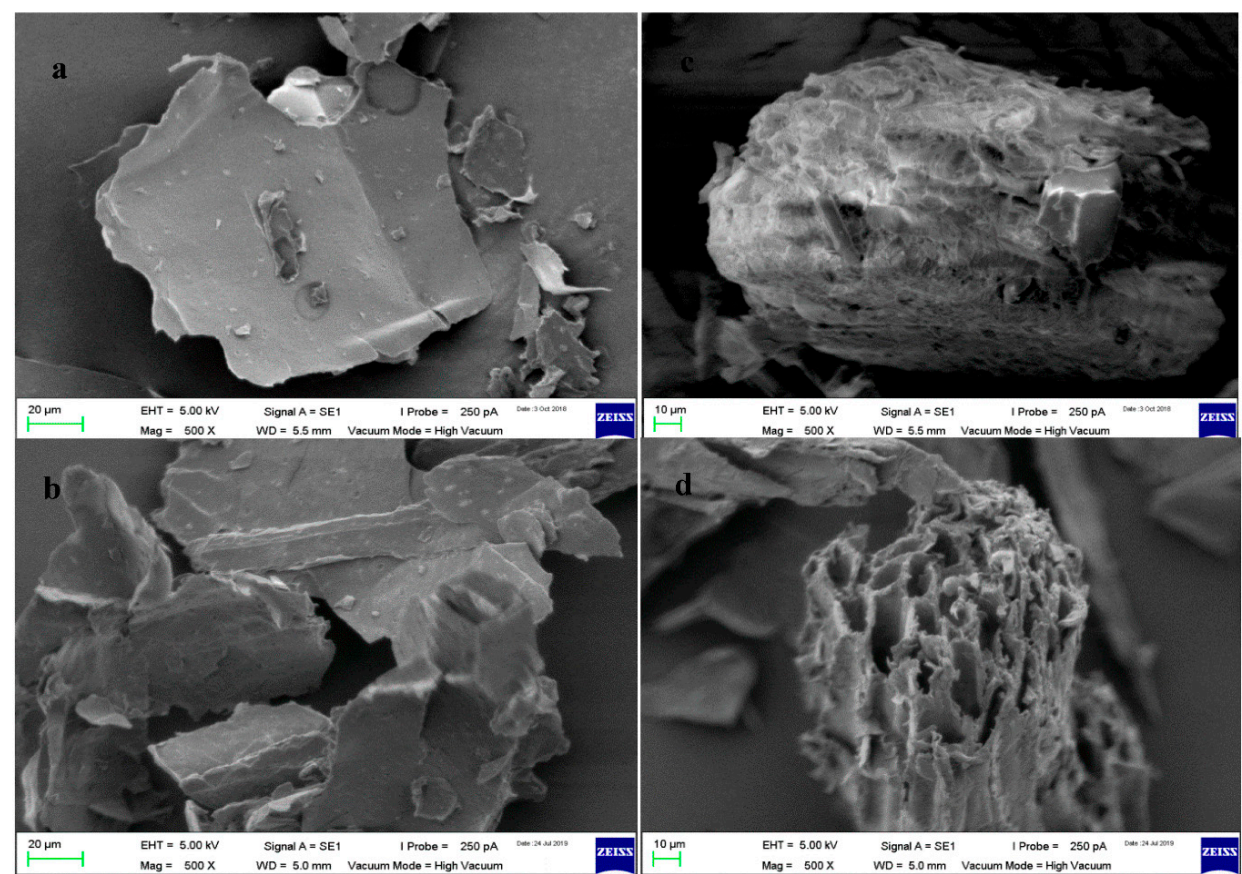

Figure 3. (a) Magnification of fiber structure for RSCB. (b) Magnification of pith structure for TSCB. (c) Magnification of pith structure for RSCB. (d) Magnification of pith structure for TSCB. 


\subsubsection{Scanning Electron Microscopy of ROBS and TOBS}

The SEM observations for the ROBS and TOBS, as illustrated in Figures 4 and 5, show a clear physical change in the flocs surface induced by thermo-chemical pre-treatment method. Figure 4 shows the general view for ROBS and TOBS, whereas Figure 5 shows the magnification of flocs surfaces for ROBS and TOBS. The alkaline-thermo pre-treatment induced a physical effect in the surface flocs
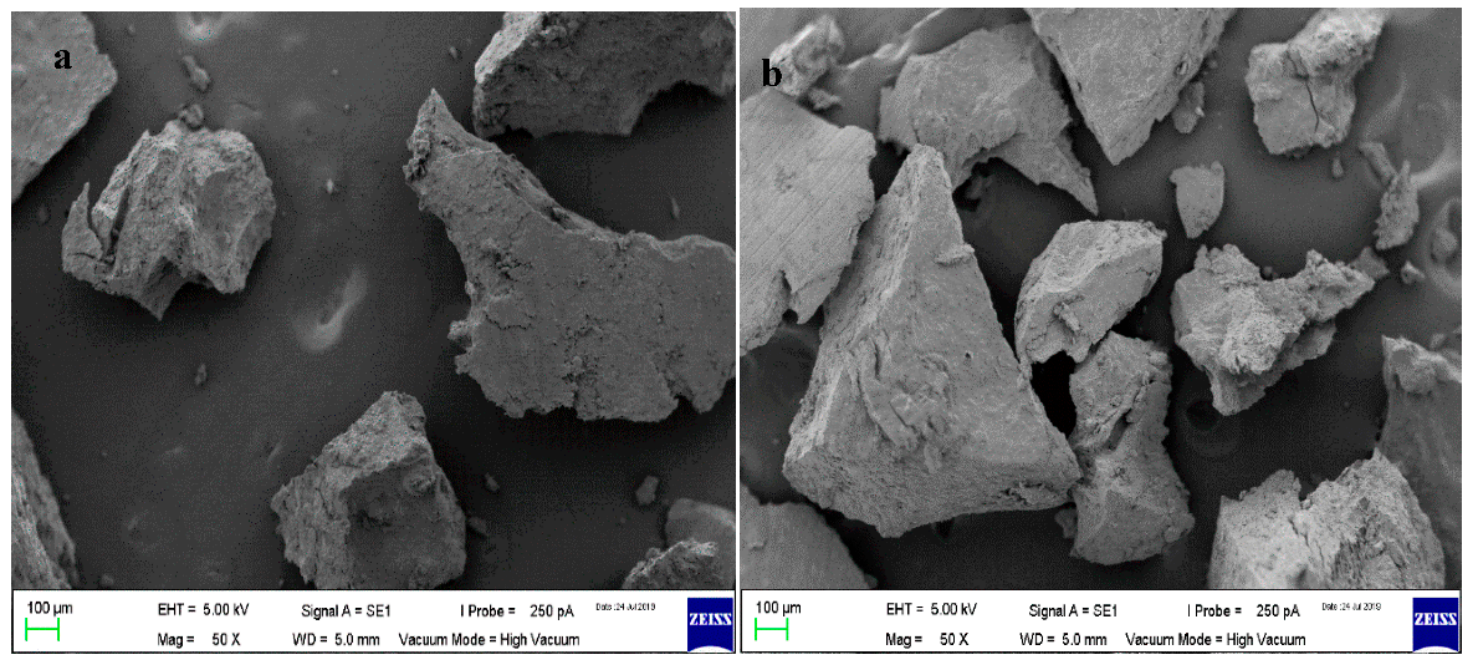

Figure 4. (a) ROBS flocs morphology. (b) TOBS flocs morphology.
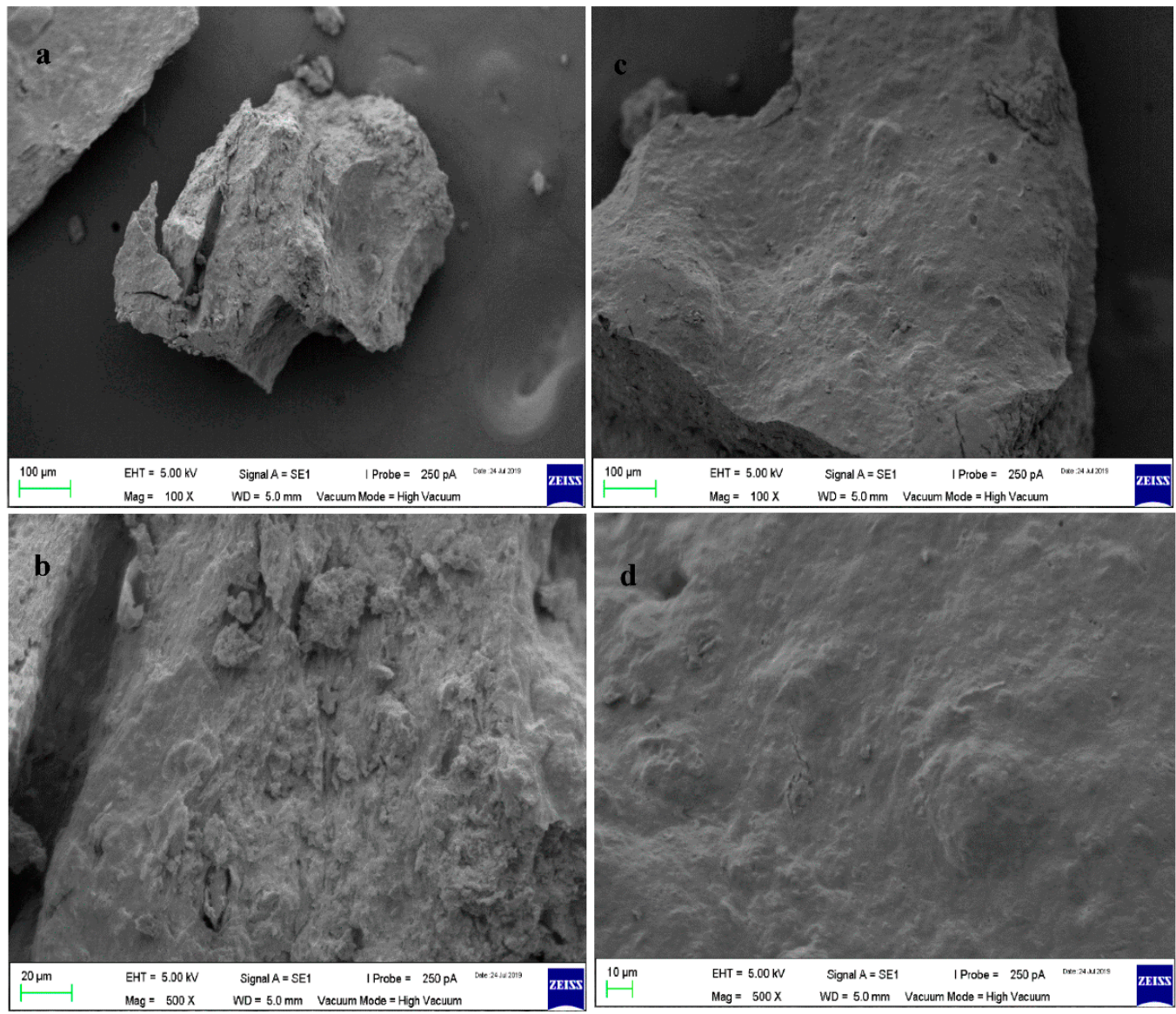

Figure 5. (a,c) Magnification of ROBS floc surface. (b,d) Magnification of TOBS floc surface. 
Figure $5 a, c$ show the magnifications of ROBS flocs, while Figure $5 c$,d show the magnification of the flocs surface for TOBS. The flocs surface of TOBS became more compact with smaller voids ratio compared to the flocs surface of the ROBS. Furthermore, the pretreatment caused more swelling and a disrupted structure in the flocs of TOBS. Therefore, the faster decomposition of the flocs by the microorganism increased the production of methane yield during anaerobic co-digestion. Similar reports for different types of sludge were reported in the literature [48,49].

3.1.6. Mixing Ratios of Treated Oily-Biological Sludge (TOBS) and Treated Sugarcane Bagasse (TSCB) to Obtain C/N Ratios between 20 and 30

Twelve batch experiments, including four replicates for the central point (medium $\mathrm{C} / \mathrm{N}$ ratio 24.2) to increase the significance and confidence levels, were designed using Equation (1), based on the ultimate and proximate results shown in Table 2, to obtain $\mathrm{C} / \mathrm{N}$ ratios between 20 and 30 . Each batch contained $2 \mathrm{~L}$ of TOBS and a matching portion of sugarcane bagasse to meet the $\mathrm{C} / \mathrm{N}$ ratio, as shown in Table 5 . The density of the TOBS was similar to water. There were three main responses in this study, namely, biogas yield, methane content, and VS removed. Prediction of the total methane yield has been published as a part of this project [32]. Table 5 shows the ratios of TOBS and TSCB added to the batch to obtain the desired $\mathrm{C} / \mathrm{N}$ ratios.

Table 5. Quantities of TOBS and TSCB added to obtain carbon/nitrogen $(\mathrm{C} / \mathrm{N})$ ratios between 20 and 30 .

\begin{tabular}{ccccc}
\hline Run No. & TSCB $(\mathbf{g})$ & TOBS $(\mathbf{g})$ & C/N & Co-Substrate VS/Inoculum VS \\
\hline 1 & 1.0 & 294.0 & 20.0 & 0.06 \\
2 & 1.0 & 243.5 & 21.1 & 0.07 \\
3 & 1.5 & 294.0 & 22.6 & 0.09 \\
4 & 1.0 & 193.0 & 22.8 & 0.09 \\
5 & 1.5 & 243.5 & 24.2 & 0.11 \\
6 & 1.5 & 243.5 & 24.2 & 0.11 \\
7 & 1.5 & 243.5 & 24.2 & 0.11 \\
8 & 1.5 & 243.5 & 24.2 & 0.11 \\
9 & 2.0 & 294.0 & 25.1 & 0.12 \\
10 & 1.5 & 193.0 & 26.5 & 0.13 \\
11 & 2.0 & 243.5 & 27.1 & 0.14 \\
12 & 2.0 & 193.0 & 30.0 & 0.18 \\
\hline
\end{tabular}

Examples to obtain C/N ratios of 20 and 30 using Equation (1) stated in the methodology.

$$
\begin{aligned}
& C / N=\frac{1.0(34.74 *(100-0)+294.0(4.31 *(100-94.20)}{1.0(0.26 *(100-0)+294.0(0.30 *(100-94.20)}=20.0 \\
& C / N=\frac{2.0(34.74 *(100-0)+193.0(4.31 *(100-94.20)}{2.0(0.26 *(100-0)+193.0(0.30 *(100-94.20)}=30.0
\end{aligned}
$$

\subsection{Kinetic of Biogas and Methane Yield}

\subsubsection{Effect of Carbon/Nitrogen $(\mathrm{C} / \mathrm{N})$ and Co-Substrate VS/Inoculum VS Ratios on} Biogas Yield

Figure 6a presents the results of daily biogas yield for four reactors with low $\mathrm{C} / \mathrm{N}$ ratios. The $\mathrm{C} / \mathrm{N}$ ratios were 20.0, 21.1, 22.6, and 22.8, respectively. Each reactor contains $2 \mathrm{~L}$ of treated oily-biological sludge and $6.8,8.21,10.20$, and $10.36 \mathrm{~g}$ of treated sugarcane bagasse, respectively. The biogas yield started from day 1 and increased gradually until day 12 . Then it remains almost constant, with some fluctuations, until day 25 . The biogas then started to slightly decrease from day 26 to the end of the reaction period, day 32 . The rapid increase initially until day 12 may be due to the high availability of accessible organic matter from TOBS and TSCB as well. From day 13 to day 25, the biogas yields were almost 
constant; this may due to the acclimatization of microorganisms with the substrates and operation environment. Meanwhile, there is still a high amount of organic matter to be consumed by the bacteria. However, the biogas yield slightly decreased from day 26 to the end of the reaction period; this indicated that most of the organic matter that can be consumed by the microorganisms under the current operation conditions was already consumed and the biogas yield started to decrease to the end of the reaction period.
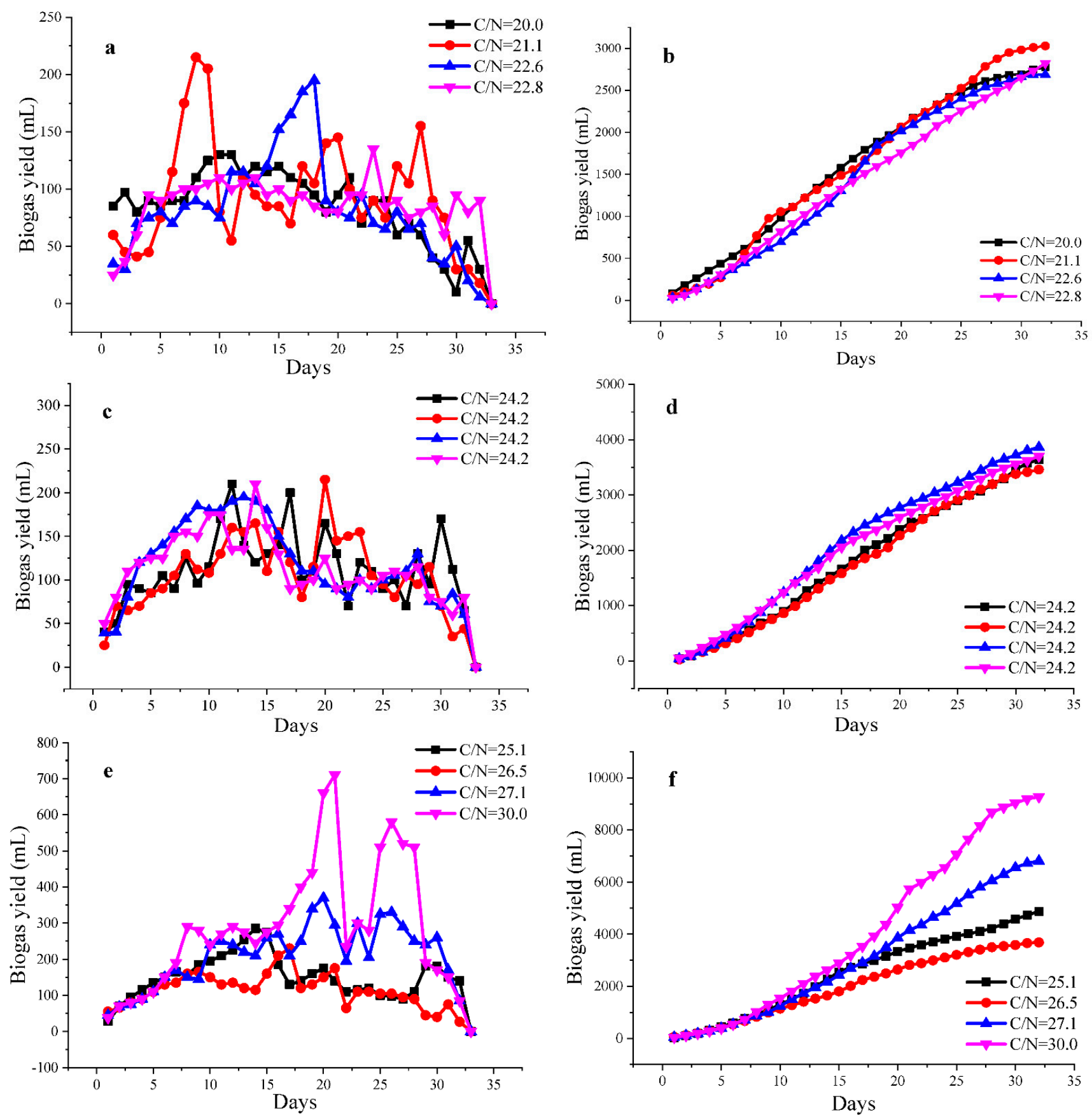

Figure 6. (a,c,e): daily biogas yield, (b,d,f): cumulative biogas yield. $\mathrm{C}$ and d are the replicates of medium C/N ratio 24.2 .

Figure $6 \mathrm{~b}$ presents the cumulative biogas yield from the four reactors. The cumulative biogas yield was 2777, 3029, 2688, and $2822 \mathrm{~mL}$, concurrent with 20, 21.1, 22.6, and 22.8 C/N ratios, respectively. The results indicate that the cumulative biogas yield from the reactor with $21.1 \mathrm{C} / \mathrm{N}$ is higher than cumulative biogas yield from the reactor with $20 \mathrm{C} / \mathrm{N}$ by $8.32 \%$. In addition, the results indicate that the cumulative biogas yield from the reactor 
with $22.8 \mathrm{C} / \mathrm{N}$ is higher than cumulative biogas yield from the reactor with $20 \mathrm{C} / \mathrm{N}$ by $1.59 \%$. The increasing biogas yield may be due to volatile solid increment together with the $\mathrm{C} / \mathrm{N}$ ratio. Overall, there is increasing of biogas yield together with $\mathrm{C} / \mathrm{N}$ ratio increment. However, the behavior of biogas yield is still not clear and needs more investigation in terms of methane yield and increasing of $\mathrm{C} / \mathrm{N}$ ratio.

Figure $6 \mathrm{c}$ shows the daily biogas yields from the central point $24.2 \mathrm{C} / \mathrm{N}$ ratio with four replicants. The behavior of daily biogas yield from the four reactors was quite similar. The biogas yield started from day 1 and increased gradually until day 14-this may be due to the high availability of degradable organic matter consumed by the microorganisms. After that, the biogas yield started to decrease from day 15 to day 18 and then remained constant with some fluctuations until day 29; this may due to a decrease in the organic matter content and the microorganisms acclimatized to the reaction environment. Then, a sharp decrease started from day 30 to day 32; this may be due to a sharp decrease in the available organic matter to be consumed by the microorganisms under the current operation conditions. When this $\mathrm{C} / \mathrm{N}$ ratio is compared to previous $\mathrm{C} / \mathrm{N}$ ratios, it is obvious that the duration of biogas' sharp increase as well as the constant period of biogas yield also increased. This may be due to the increasing of the $\mathrm{C} / \mathrm{N}$ ratio by increasing the dosage of TSCB, as therefore the content of organic matter will increase, and the microorganisms will work more effectively.

Figure $6 \mathrm{~d}$ shows the cumulative biogas yield from four reactors with the same $\mathrm{C} / \mathrm{N}$ ratio, which is the central point 24.2. The cumulative biogas yields were 3638, 3459, 3863 , and $3700 \mathrm{~mL}$ respectively. The average biogas yield is $3665 \mathrm{~mL}$; this is higher than cumulative biogas yield from reactors with 20.0 and $22.8 \mathrm{C} / \mathrm{N}$ ratios by $24.23 \%$ and $23.0 \%$, respectively. It is clear that the increasing biogas yield in this $\mathrm{C} / \mathrm{N}$ ratio was enhanced greatly compared to the enhancement among the previous ratios. This indicates that the behavior of biogas is much clearer when increasing the $\mathrm{C} / \mathrm{N}$ ratio by increasing the dosage of TSCB.

Figure 6e presents the daily biogas yield from the 25.1, 26.5, 27.1, and $30.0 \mathrm{C} / \mathrm{N}$ ratios. The behavior of biogas yield from the four reactors was quite similar. The biogas yield started increasing gradually from day 1 to day 7; this may be due to the high availability of degradable organic matter consumed by the microorganisms. After that, the 25.1 and $26.5 \mathrm{C} / \mathrm{N}$ ratio reactors almost remain constant, with a slight decrease and some fluctuations from day 8 to day 30 , which may be due to a decrease in the organic matter content and the microorganisms acclimatized to the reaction environment. The 27.1 and $30.0 \mathrm{C} / \mathrm{N}$ ratio reactors remain constant, with a slight increase and some fluctuations from day 8 to day 30 . This may be due to the acclimatization of microorganisms with the reaction environment and more availability of organic matter compared to 25.1 and $26.5 \mathrm{C} / \mathrm{N}$ reactors due to the increasing TSCB dosage. Then, a sharp decrease started from day 30 to day 32; this may due to the sharp decrease in the available organic matter to be consumed by the microorganisms under the current operation conditions. When these $\mathrm{C} / \mathrm{N}$ ratios are compared to previous $\mathrm{C} / \mathrm{N}$ ratios, it is obvious that the constant period of biogas yield increased. This may be due to increasing the $\mathrm{C} / \mathrm{N}$ ratios to high levels by increasing the dosage of TSCB, as therefore the content of organic matter will increase and the microorganisms will work more effectively compared to lower volatile solids reactors.

Figure $6 \mathrm{f}$ shows the cumulative biogas yield from $25.1,26.5,27.1$ and $30.0 \mathrm{C} / \mathrm{N}$ ratios. The cumulative biogas yields were $4867,3683,6808$, and $9268 \mathrm{~mL}$, respectively. The results indicate that the cumulative biogas yields from reactor with $30.0 \mathrm{C} / \mathrm{N}$ is higher than the cumulative biogas yields from reactors with $25.1,24.2$ and $20 \mathrm{C} / \mathrm{N}$ by $47.39 \%, 60.46 \%$, and $70.04 \%$, respectively. It is clear that increasing the biogas yield by gradually increasing the $\mathrm{C} / \mathrm{N}$ ratio to higher levels is highly enhanced compared to the biogas yield from the lower $\mathrm{C} / \mathrm{N}$ ratios. Overall, the yield of biogas increased gradually while increasing the $\mathrm{C} / \mathrm{N}$ ratio by increasing the dosage of TSCB. This may be due to the fact that increasing the dosage of TSCB will result in increasing the volatile solids content. Therefore, the microorganisms' activity is enhanced and they are better acclimatized to the reaction environment, and the 
biogas yield will enhance as well. In addition, at high $\mathrm{C} / \mathrm{N}$ ratios between 25.1 and 30.0, the $\mathrm{pH}$ after 5 days of the reaction was stable between 6.9 and 7.3, which is within the ideal range of $\mathrm{pH}$ for better biogas production during anaerobic digestion, namely between 6.8-7.4, which provides a more healthy environment for bacteria [50,51]. Meanwhile, the lower $\mathrm{C} / \mathrm{N}$ ratios cause ammonia inhabitation and the $\mathrm{pH}$ values increased and become toxic and inhibit the growth of methanogenic bacteria [52-55]. $\mathrm{C} / \mathrm{N}$ ratios between 25 and 30 were also commonly found during previous studies to be better ratios during the anaerobic digestion process, with the $\mathrm{C} / \mathrm{N} 30$ ratio being the most common ratio [53,56-59], and this is consistent with the results of this study. Therefore, $\mathrm{C} / \mathrm{N} 30$ was selected from this study for the maximum biogas and methane yield and was validated using three replicates. The average after three-replicate validation of the maximum biogas yield form C/N 30 was found to be $9035.0 \mathrm{~mL}$ (195.6 mL / $\mathrm{g} \mathrm{VS}_{\text {removed }}$ ), with the significance level being more than $95 \%$.

\section{ANOVA Analysis for Biogas Yield from C/N 20-30}

Appendix A, Table A1 summarizes the ANOVA analysis for 20.0-22.8 C/N ratios; it shows that there is no significant difference in the daily biogas yield, with a $p$ value $>0.05$. This indicates that the dosage of TSCB added is still not enough to achieve a significant difference in the biogas yield from reactors with a low $\mathrm{C} / \mathrm{N}$ ratio. Appendix $\mathrm{A}$, Table $\mathrm{A} 2$ summarizes the ANOVA analysis for 20.0-24.2 C/N ratios; it shows that there is a significant difference in daily biogas yield, a with $p$ value $<0.05$. This indicates that the dosage of TSCB added can cause a significant difference in the biogas yield from reactors when the $\mathrm{C} / \mathrm{N}$ ratio increases to 24.2. Appendix A, Table A3 summarizes the ANOVA analysis for $25.1-30.0 \mathrm{C} / \mathrm{N}$ ratios; it shows that there is a significant difference in daily biogas yield, with a $p$ value $<0.05$. This indicates that a larger dosage of TSCB added can achieve a highly significant difference in the biogas yield from reactors when the $\mathrm{C} / \mathrm{N}$ ratio increases to 30.0. Appendix A, Table A4 summarizes the ANOVA analysis for 20.0-30.0 C/N ratios, and it shows that there is a significant difference in daily biogas yield, with a $p$ value $<0.05$. This indicates that the overall increment for the dosage of TSCB added can achieve a significant difference in the biogas yield from reactors. Therefore, the $\mathrm{C} / \mathrm{N}$ ratio is a key factor affecting the production of biogas; increasing the $\mathrm{C} / \mathrm{N}$ ratio by adding more TSCB results in an increase in the biogas yield, and vice versa.

\subsubsection{Effect of Carbon/Nitrogen $(\mathrm{C} / \mathrm{N})$ and Co-Substrate VS/Inoculum VS Ratios on Methane Yield}

Figure 7a presents the results of the 3-day interval methane yield for four reactors with a low $\mathrm{C} / \mathrm{N}$ ratio. The $\mathrm{C} / \mathrm{N}$ ratios were $20.0,21.1,22.6$, and 22.8 , respectively. The measurement of the methane yield started from day 3 and the methane yield increased gradually until day 24 , with some fluctuations. The methane content mainly related to the biogas yield quantity, as well the duration of reaction. When there was an increase in biogas yield, the methane content also increased and continued to gradually increase until day 24. Then, from day 25 to the end of the reaction, the methane yield sharply decreased; this may due to the fact that the biogas yield also sharply decreased as a result of the fact that most of the organic matter that can be consumed by the microorganisms under the current operation conditions was already consumed and the biogas yield started to decrease to the end of the reaction period.

Figure $7 \mathrm{~b}$ presents the cumulative methane yield from the four reactors. The cumulative methane yield was 980.0, 1023.80, 1051.28, and $1067.28 \mathrm{~mL}$, concurrent with 20, 21.1, 22.6 , and $22.8 \mathrm{C} / \mathrm{N}$ ratios, respectively. The results indicate that the cumulative methane yield from the reactor with $21.1 \mathrm{C} / \mathrm{N}$ is higher than cumulative biogas yield from the reactor with $20 \mathrm{C} / \mathrm{N}$ by $6.78 \%$. In addition, the results indicate that the cumulative biogas yield from reactor with $22.8 \mathrm{C} / \mathrm{N}$ is higher than cumulative biogas yield from reactor with $20 \mathrm{C} / \mathrm{N}$ by $8.18 \%$. The increase in the methane yield is not high. However, the overall view of methane yield from these reactors shows that there is gradual increase in the methane yield together with the $\mathrm{C} / \mathrm{N}$ ratio increment. The stability of the increase in the methane 
yield is greater compared to the biogas yield. This may be due to the fact that the $\mathrm{C} / \mathrm{N}$ ratio increment highly affects the methane yield compared to the biogas yield.
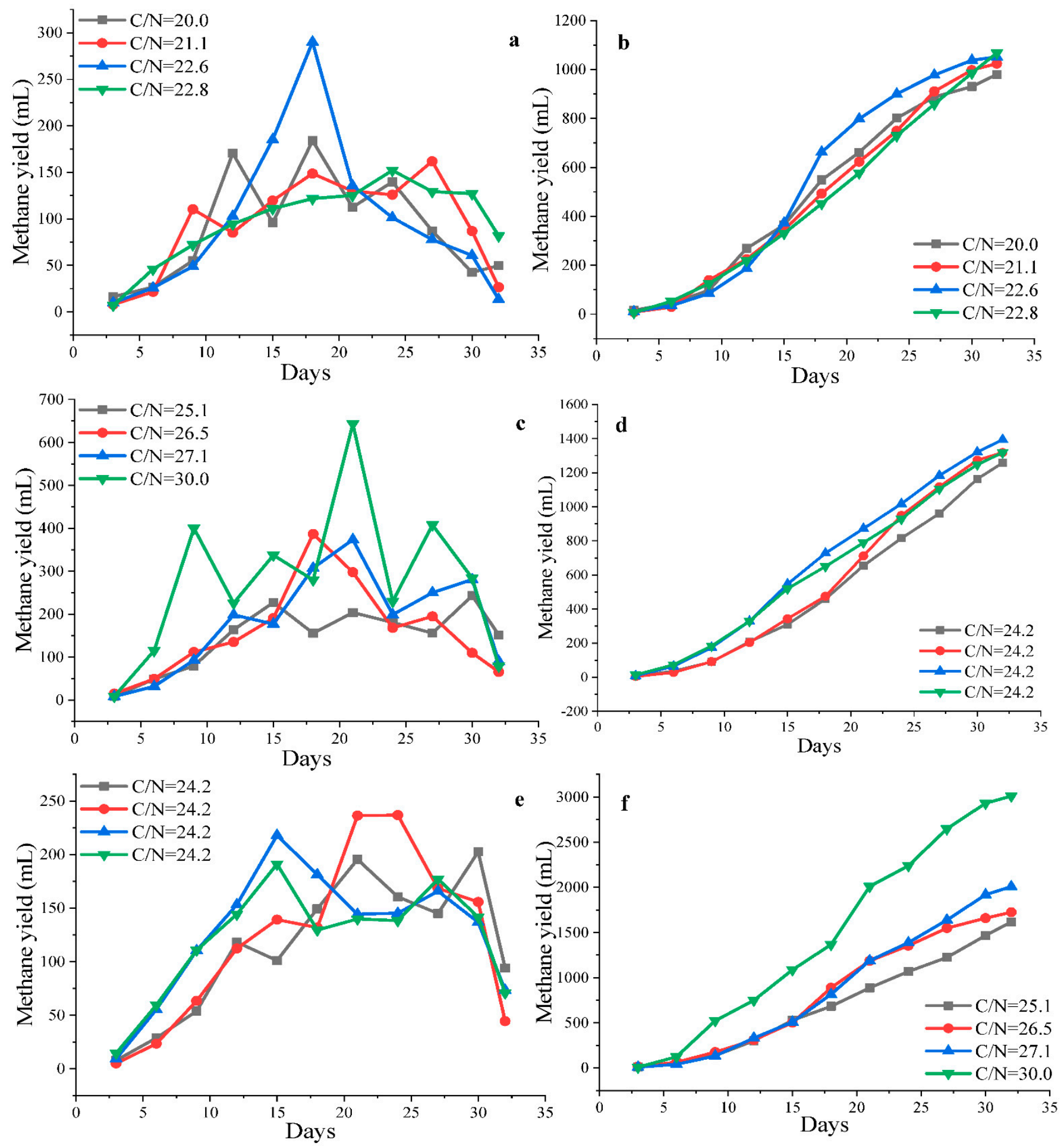

Figure 7. (a,c,e) Methane content yield every three days; (b,d,f) cumulative methane yield. $\mathbf{c}$ and $\mathrm{d}$ are the replicates of medium $\mathrm{C} / \mathrm{N}$ ratio 24.2 .

Figure $7 \mathrm{c}$ presents the results of the 3-day interval methane yield for four replicates of reactors with a central $\mathrm{C} / \mathrm{N}$ ratio of 24.2. The measurement of methane yield started from day 3 and the methane yield increased gradually until day 15 with some fluctuations. 
The methane content is mainly related to the biogas yield quantity as well the duration of the reaction. The biogas yield from day 16 until day 30 experienced a constant production rate with some fluctuations. Therefore, the methane yield was constant as well during this period. Then, the methane content from day 30 to the end of the reaction shows a sharp decrease in methane content, and this is mainly related to the sharp decrease noted in the biogas yield during this time.

Figure $7 \mathrm{~d}$ presents the cumulative methane yield from the four replicate reactors. The cumulative methane yield was $1257.29,1317.53,1393.38$, and $1317.57 \mathrm{~mL}$, concurrent with the same $\mathrm{C} / \mathrm{N}$ ratio of 24.2 . The average methane yield is $1321.42 \mathrm{~mL}$. The results indicate that the average cumulative methane yield from the reactor with $24.2 \mathrm{C} / \mathrm{N}$ is higher than the cumulative biogas yield from the reactor with $20 \mathrm{C} / \mathrm{N}$ by $25.84 \%$. In addition, the results indicate that the average cumulative biogas yield from reactors with $24.2 \mathrm{C} / \mathrm{N}$ is higher than cumulative biogas yield from the reactor with $22.8 \mathrm{C} / \mathrm{N}$ by $19.24 \%$. The increase in the methane yield from this ratio is high and promising compared to previous ratios.

Figure 7e presents the results of a 3-day interval methane yield for four reactors with a low $\mathrm{C} / \mathrm{N}$ ratio. The $\mathrm{C} / \mathrm{N}$ ratios were $25.1,26.5,27.1$, and 30.0 , respectively. The measurement of the methane yield started from day 3 and the methane yield increased gradually until day 15 with some fluctuations. The methane content was mainly related to the biogas yield as well the duration of reaction. The methane yield then experienced stability with some fluctuations until day 30 . This may be due to the constant production of biogas during this period. Then, from day 30 to the end of the reaction, the methane yield sharply decreased due to the sharp decrease in the biogas yield.

Figure $7 \mathrm{f}$ presents the cumulative methane yield from the four reactors. The cumulative methane yield was $1617.18,1723.40,2007.84$, and $3009.46 \mathrm{~mL}$ concurrent with 25.1, 26.5, 27.1 , and $30.0 \mathrm{C} / \mathrm{N}$ ratios, respectively. The results indicate that the cumulative methane yield from the reactor with $25.1 \mathrm{C} / \mathrm{N}$ is higher than cumulative biogas yield from the reactor with $24.2 \mathrm{C} / \mathrm{N}$ by $18.29 \%$. In addition, the results indicate that the cumulative biogas yield from the reactor with $30.0 \mathrm{C} / \mathrm{N}$ is higher than cumulative biogas yield from the reactor with $25.1 \mathrm{C} / \mathrm{N}$ by $46.26 \%$. The results also indicate that the cumulative biogas yield from the reactor with $30.0 \mathrm{C} / \mathrm{N}$ is higher than the cumulative biogas yield from the reactor with $20.0 \mathrm{C} / \mathrm{N}$ by $67.44 \%$. The increase in the methane yield is very high compared to previous $\mathrm{C} / \mathrm{N}$ ratios. Overall, the methane yield was more stable and gradually increased in accordance with the $\mathrm{C} / \mathrm{N}$ ratio increment compared to the biogas yield. The average of three-replicates validation for the maximum methane yield form $\mathrm{C} / \mathrm{N} 30$ was found to be $2996.07 \mathrm{~mL}$ ( $64.85 \mathrm{~mL} \mathrm{CH}_{4} / \mathrm{g} \mathrm{VS}_{\text {removed }}$ ), with a significance level of more than $95 \%$.

The thermo-chemical pre-treatment of the sludge also contributes to the increased convertibility of the organic matter to biogas, which is similar to the observation by David $C$ [60] during his study on the effect of thermal pre-treatment on waste activated sludge. He found that the increment of methane content increased concurrently with a temperature increment up to a maximum of $175^{\circ} \mathrm{C}$. Apart from that, different studies showed that the thermal and thermo-chemical pre-treatment increased the digestibility of the sludge during the anaerobic digestion process $[61,62]$. The thermo-chemical pre-treatment for sugarcane bagasse had a significant effect on enhancing biodegradability rate, which resulted in higher biogas production as well as methane content. This was also noticed by Costa [63] during his study on the effect of thermo-chemical pre-treatment to improve the anaerobic digestion of sugarcane bagasse.

\section{ANOVA Analysis for Methane Yield}

Although ANOVA analysis showed a non-significant increase in the methane yield during the lower increment of $\mathrm{C} / \mathrm{N}$ ratios, as shown in Appendix B, Table A5, Table A6, and Table A7, there was a significant difference in the methane yield during the high increment of $\mathrm{C} / \mathrm{N}$ ratios, as shown in Table A8, with a $p$-value of less than 0.05 . This indicates that the increment of $\mathrm{C} / \mathrm{N}$ and co-substrate VS/inoculum VS ratios has a higher effect on biogas yield than methane content. However, the methane yield production is more stable and 
gradually increased together with $\mathrm{C} / \mathrm{N}$ ratios increment without fluctuations compared to the biogas yield.

\subsubsection{Effect of Carbon/Nitrogen $(\mathrm{C} / \mathrm{N})$ and Co-Substrate VS/Inoculum VS Ratios on} Volatile Solids Removed

The VS removed increased progressively with $\mathrm{C} / \mathrm{N}$ and co-substrate VS/inoculum VS ratios. According to Table 6, the minimum VS removed was met with minimum C/N and co-substrate VS/inoculum VS ratios. In contrast, the maximum VS removed was met with maximum C/N and co-substrate VS/inoculum VS ratios (30 and 0.18). The removal of volatile solids between minimum and maximum biogas and methane yields increased by $30.09 \%$ at $\mathrm{C} / \mathrm{N} 30$. The stable range of $\mathrm{pH}$ for all reactors was found to be between 6.9 and 8.0, and this was required for a proper environment for better microorganism activities. Therefore, the stability of a $\mathrm{pH}$ of 6.9-7.3, which is healthier for microorganisms at C/N 25.1-30, contributed to the higher removal of volatile solids and resulted in higher biogas and methane production. Alagöz and Maragkaki $[64,65]$ indicated that VS removal improved during the co-digestion process for sludge with agricultural wastes, while the production of methane yields improved.

Table 6. Biogas yield and methane content vs. carbon/nitrogen and co-substrate VS/inoculum VS ratios.

\begin{tabular}{cccccc}
\hline Run No. & C/N & $\begin{array}{c}\text { Volatile Solids } \\
\text { Removed (g) }\end{array}$ & Biogas Yield (mL) & Methane Yield (mL) & $\begin{array}{c}\text { Biogas Yield/VS Removed } \\
\text { mL/g.VS }\end{array}$ \\
\hline 1 & 20.0 & 32.3 & 2777 & 980.0 & 86.0 \\
\hline 2 & 21.1 & 32.5 & 3029 & 1023.8 & 93.2 \\
\hline 3 & 22.6 & 33.2 & 2688 & 1051.3 & 81.0 \\
\hline 4 & 22.8 & 33.4 & 2822 & 1067.3 & 84.5 \\
\hline 5 & 24.2 & 34.8 & 3638 & 1257.3 & 104.5 \\
\hline 6 & 24.2 & 35.1 & 3459 & 1317.5 & 98.5 \\
\hline 7 & 24.2 & 36.1 & 3863 & 1393.4 & 107.0 \\
\hline 8 & 24.2 & 35.6 & 3700 & 1317.6 & 103.9 \\
\hline 9 & 25.1 & 39.2 & 4867 & 1617.3 & 124.2 \\
\hline 10 & 26.5 & 39.8 & 3683 & 1723.3 & 92.5 \\
\hline 11 & 27.1 & 42.2 & 6808 & 2007.9 & 161.3 \\
\hline 12 & 30.0 & 46.2 & 9268 & 3009.3 & 200.6 \\
\hline
\end{tabular}

Table 7 shows the comparison of the current study with different studies used anaerobic co-digestion technology. This study shows better results than other studies in terms of biogas yield. However, the methane yield was lower than other studies. This may be due to the differences in materials' characteristics and co-digestion operational conditions. The present study indicated that anaerobic co-digestion using a co-substrate with a high $\mathrm{C} / \mathrm{N}$ ratio and VS content to balance the lower $\mathrm{C} / \mathrm{N}$ ratio of the oily-biological sludge would enhance the digestibility, resulting in higher biogas and methane yields in case we used mono-digestion. However, to increase the methane yield from oily-biological sludge with sugarcane bagasse, the pre-treatment method or parameters for both materials can be changed and tested. For instance, the delignification process for sugarcane bagasse using thermo-chemical method can be optimized using the response surface methodology to minimize the lignin content. In addition, another pre-treatment method can be applied. In addition, for the oily-biological sludge, the pre-treatment parameters and method can also be changed. For example, we can increase the temperature and reduce the time when using thermo-chemical method, or use a different pre-treatment method such as ultrasonic pre-treatment. In addition, we can test the methane yield by changing the operational condition during the anaerobic co-digestion process or by changing the type of digestion 
method. For instance, we can change the temperature from a mesophilic thermophilic condition or decrease the mixing speed during the co-digestion process. In addition, changing the type of digestion method could enhance the methane yield, such as using the two-stage anaerobic co-digestion method.

Table 7. Various substrates to enhance biogas yields during the anaerobic co-digestion process.

\begin{tabular}{|c|c|c|c|c|}
\hline Substrate & Co-Substrate & Biogas and Methane Yield & Digestion Time (Batch) & Reference \\
\hline Oil refinery wastewater & Sugarcane bagasse & $\begin{array}{c}154.72 \mathrm{~mL} / \mathrm{g} \mathrm{VS}, \\
97.13 \mathrm{~mL}^{\circ} \mathrm{CH}_{4} / \mathrm{g} \text { VS }\end{array}$ & 34 days & [66] \\
\hline Waste activated sludge & Grape pomace & $\begin{array}{c}180 \mathrm{~mL} / \mathrm{gVS}_{\text {removed }} \\
110 \mathrm{~mL} \text { of } \mathrm{CH}_{4} / \mathrm{gVS}_{\text {removed }}\end{array}$ & 30 days & [67] \\
\hline Oil refinery biological sludge & Sugarcane bagasse & $\begin{array}{c}200.6 \mathrm{~mL} / \mathrm{g} \mathrm{VS}_{\text {removed }} \\
63.52 \mathrm{~mL} \text { of } \\
\mathrm{CH}_{4} / \mathrm{gVS}_{\text {removed }} \\
\end{array}$ & 33 days & This study \\
\hline
\end{tabular}

\section{Conclusions}

In this study, sugarcane bagasse was used as a high $\mathrm{C} / \mathrm{N}$ ratio co-substrate to treat the low $\mathrm{C} / \mathrm{N}$ ratio oily-biological sludge through anaerobic co-digestion technology. Thermochemical pre-treatment using $\mathrm{NaOH}$ was carried out for sugarcane bagasse to reduce the lignin content as well as to increase the $\mathrm{pH}$. The best ratio for the sugarcane delignification process as a part of pre-treatment was $1 \%(w / v)$ sodium hydroxide, 1:10 solid-liquid ratio, at $100{ }^{\circ} \mathrm{C}$, and $150 \mathrm{rpm}$ for $1 \mathrm{~h}$. In addition, thermo-chemical pre-treatment were carried out for the oily-biological sludge using $\mathrm{NaOH}$ to increase the sludge digestibility and to increase the $\mathrm{pH}$ as well. The gradual increase in the $\mathrm{C} / \mathrm{N}$ ratio resulted in a gradual rise in sugarcane bagasse content along with co-substrate volatile solids/inoculum volatile solids. Therefore, the biogas yield and methane content increased when higher $\mathrm{C} / \mathrm{N}$ and co-substrate VS/inoculum VS were used. The biogas yield from $\mathrm{C} / \mathrm{N} 30$ was higher than the biogas yield from $\mathrm{C} / \mathrm{N} 20$ by $70.04 \%$. Meanwhile, the methane yield from $\mathrm{C} / \mathrm{N} 30$ was higher than the methane yield from $\mathrm{C} / \mathrm{N} 20$ by $67.44 \%$. The maximum biogas and methane yield coincided with the highest $\mathrm{C} / \mathrm{N}$ and co-substrate VS/inoculum VS ratios (30.0 and 0.18 ) with $200.6 \mathrm{~mL} / \mathrm{g} \mathrm{VS}_{\text {removed }}$ and $65.1 \mathrm{~mL} \mathrm{CH}_{4} / \mathrm{g} \mathrm{VS}_{\text {removed, }}$, respectively. This increase was attributed to the increment of volatile solids content while increasing the $\mathrm{C} / \mathrm{N}$ ratios. In addition, it was due to the stability of $\mathrm{pH}$ for high $\mathrm{C} / \mathrm{N}$ ratios reactors between 6.9 and 7.3, which is more healthy for microorganisms activities. The lower $\mathrm{C} / \mathrm{N}$ ratios cause an increased ammonia concentration, which is toxic to the bacteria, resulting in a lower biogas and methane yield.

Author Contributions: Conceptualization, S.R.M.K. and A.A.S.G.; methodology, A.A.S.G.; software, A.A.S.G.; validation, A.A.S.G., S.R.M.K. and A.H.J.; formal analysis, A.A.S.G.; investigation, S.R.M.K.; resources, A.A.S.G. and S.R.M.K.; data curation, A.A.S.G. and G.H.A.S.; writing-original draft preparation, A.A.S.G.; writing-review and editing, A.A.S.G., A.N., V.K., N.M.Y.A. and B.N.S.A.-d.; visualization, A.A.S.G. and A.A.H.S.; supervision, S.R.M.K.; project administration, S.R.M.K.; funding acquisition, S.R.M.K. and G.H.A.S. All authors have read and agreed to the published version of the manuscript.

Funding: This work was funded by Universiti Tenaga Nasional (UNITEN) under the iRMC BOLD Publication Fund.

Data Availability Statement: This project still on going and the data cannot be published at the current stage because there might be more analysis and comparison of the data after anaerobic co-digestion process under thermophilic condition. However, in case any researcher needs the data can either contact us via email or use Digitizer Plot for the graphs to extract the data.

Acknowledgments: Authors would like to thank Department of Civil and Environmental Engineering, Universiti Teknologi PETRONAS and Yayasan UTP for their support, funding and contribution to this work under grant cost center 015LC0050. Also, the authors would like to acknowledge Universiti Tenaga Nasional (UNITEN). 
Conflicts of Interest: The authors declare no conflict of interest.

Novelty Statement: To the authors' best knowledge, there is no published analysis of the anaerobic co-digestion of oily-biological sludge generated from petroleum refineries' wastewater treatment system with sugarcane bagasse under mesophilic or thermophilic conditions. This study used mesophilic anaerobic co-digestion technology. Both mechanical and thermo-chemical pre-treatment methods were applied to the raw materials prior to the digestion process to enhance the digestibility and improve microorganism activities by reducing the lignin content of sugarcane bagasse and increasing the sludge solubilization and stabilization. Due to the acidic nature of the sludge and sugarcane bagasse, $\mathrm{NaOH}$ was used during the pre-treatment process to adjust the $\mathrm{pH}$ during the anaerobic co-digestion process within 6-8. The design for the batch mixtures was determined based on $\mathrm{C} / \mathrm{N}$ ratios and co-substrate VS/inoculum VS ratios to analyse their effects on biogas yield, methane content, and VS removed. A part of this project was recently published in the Sustainability journal, which contains the prediction of methane yield from this design [32]. However, this study focused and extended on the analysis, the characterization of thermo-chemically pre-treated materials, as well as the kinetics of daily biogas yields, along with interval methane yields using one-way ANOVA analysis, and the effects of $\mathrm{C} / \mathrm{N}$ ratios with co-substrate VS/inoculum VS ratios on total biogas and methane yield.

\section{Appendix A}

Table A1. One-way (ANOVA) test for daily biogas yield from the first four reactors.

\begin{tabular}{|c|c|c|c|c|c|c|}
\hline $\begin{array}{c}\text { Anova: Single Factor } \\
\text { SUMMARY }\end{array}$ & & & & & & \\
\hline Groups & Count & Sum & Average & Variance & & \\
\hline $\mathrm{C} / \mathrm{N}=20.0$ & 32 & 2777 & 86.78125 & 923.1442 & & \\
\hline $\mathrm{C} / \mathrm{N}=21.1$ & 32 & 3029 & 94.65625 & 2288.426 & & \\
\hline $\mathrm{C} / \mathrm{N}=22.6$ & 32 & 2688 & 84 & 1946.71 & & \\
\hline $\mathrm{C} / \mathrm{N}=22.8$ & 32 & 2822 & 88.1875 & 428.3508 & & \\
\hline \multicolumn{7}{|l|}{ ANOVA } \\
\hline Source of Variation & SS & $d f$ & MS & $F$ & p-value & F crit \\
\hline Between Groups & 1957.313 & 3 & 652.4375 & 0.467142 & 0.705731 & 2.677699 \\
\hline Within Groups & $173,185.6$ & 124 & 1396.658 & & & \\
\hline Total & $175,142.9$ & 127 & & & & \\
\hline
\end{tabular}

Table A2. One-way (ANOVA) test for daily biogas yield from the first five reactors.

\begin{tabular}{|c|c|c|c|c|c|c|}
\hline $\begin{array}{l}\text { Anova: Single Facto } \\
\text { SUMMARY }\end{array}$ & & & & & & \\
\hline Groups & Count & Sum & Average & Variance & & \\
\hline $\mathrm{C} / \mathrm{N}=20.0$ & 32 & 2777 & 86.78125 & 923.1442 & & \\
\hline $\mathrm{C} / \mathrm{N}=21.1$ & 32 & 3029 & 94.65625 & 2288.426 & & \\
\hline $\mathrm{C} / \mathrm{N}=22.6$ & 32 & 2688 & 84 & 1946.71 & & \\
\hline $\mathrm{C} / \mathrm{N}=22.8$ & 32 & 2822 & 88.1875 & 428.3508 & & \\
\hline Ave $\mathrm{C} / \mathrm{N}=24.2$ & 32 & 3665 & 114.5313 & 1083.051 & & \\
\hline \multicolumn{7}{|l|}{ ANOVA } \\
\hline Source of Variation & SS & $d f$ & MS & $F$ & p-value & F crit \\
\hline Between Groups & $19,429.71$ & 4 & 4857.428 & 3.641424 & 0.007262 & 2.430002 \\
\hline Within Groups & $206,760.2$ & 155 & 1333.936 & & & \\
\hline Total & $226,189.9$ & 159 & & & & \\
\hline
\end{tabular}


Table A3. One-way (ANOVA) test for daily biogas yield from the last four reactors.

\begin{tabular}{|c|c|c|c|c|c|c|}
\hline \multicolumn{7}{|c|}{$\begin{array}{c}\text { Anova: Single Factor } \\
\text { SUMMARY }\end{array}$} \\
\hline Groups & Count & Sum & Average & Variance & & \\
\hline $\mathrm{C} / \mathrm{N}=25.1$ & 32 & 4867 & 152.0938 & 3291.184 & & \\
\hline $\mathrm{C} / \mathrm{N}=26.5$ & 32 & 3683 & 115.0938 & 2190.152 & & \\
\hline $\mathrm{C} / \mathrm{N}=27.1$ & 32 & 6808 & 212.75 & 7365.226 & & \\
\hline $\mathrm{C} / \mathrm{N}=30.0$ & 32 & 9268 & 289.625 & $30,224.18$ & & \\
\hline \multicolumn{7}{|l|}{ ANOVA } \\
\hline Source of Variation & $S S$ & $d f$ & MS & $F$ & p-value & F crit \\
\hline Between Groups & $558,965.5$ & 3 & $186,321.8$ & 17.3038 & $1.9 \times 10^{-9}$ & 2.677699 \\
\hline Within Groups & $1,335,193$ & 124 & $10,767.68$ & & & \\
\hline Total & $1,894,158$ & 127 & & & & \\
\hline
\end{tabular}

Table A4. One-way (ANOVA) test for daily biogas yield from all reactors.

\begin{tabular}{|c|c|c|c|c|c|c|}
\hline \multicolumn{7}{|c|}{$\begin{array}{c}\text { Anova: Single Factor } \\
\text { SUMMARY }\end{array}$} \\
\hline Groups & Count & Sum & Average & Variance & & \\
\hline $\mathrm{C} / \mathrm{N}=20.0$ & 32 & 2777 & 86.78125 & 923.1442 & & \\
\hline $\mathrm{C} / \mathrm{N}=21.1$ & 32 & 3029 & 94.65625 & 2288.426 & & \\
\hline $\mathrm{C} / \mathrm{N}=22.6$ & 32 & 2688 & 84 & 1946.71 & & \\
\hline $\mathrm{C} / \mathrm{N}=22.8$ & 32 & 2822 & 88.1875 & 428.3508 & & \\
\hline Ave $C / N=24.2$ & 32 & 3665 & 114.5313 & 1083.051 & & \\
\hline $\mathrm{C} / \mathrm{N}=25.1$ & 32 & 4867 & 152.0938 & 3291.184 & & \\
\hline $\mathrm{C} / \mathrm{N}=26.5$ & 32 & 3683 & 115.0938 & 2190.152 & & \\
\hline $\mathrm{C} / \mathrm{N}=27.1$ & 32 & 6808 & 212.75 & 7365.226 & & \\
\hline $\mathrm{C} / \mathrm{N}=30.0$ & 32 & 9268 & 289.625 & $30,224.18$ & & \\
\hline \multicolumn{7}{|l|}{ ANOVA } \\
\hline Source of Variation & $S S$ & $d f$ & MS & $F$ & p-value & F crit \\
\hline Between Groups & $1,271,971$ & 8 & $158,996.4$ & 28.76871 & $1.61 \times 10^{-32}$ & 1.971665 \\
\hline Within Groups & $1,541,953$ & 279 & 5526.714 & & & \\
\hline Total & $2,813,924$ & 287 & & & & \\
\hline
\end{tabular}

\section{Appendix B}

Table A5. One-way (ANOVA) test for methane yield every three days from the first four reactors.

\begin{tabular}{|c|c|c|c|c|c|c|}
\hline \multicolumn{7}{|c|}{$\begin{array}{c}\text { Anova: Single Factor } \\
\text { SUMMARY }\end{array}$} \\
\hline Groups & Count & Sum & Average & Variance & & \\
\hline $\mathrm{C} / \mathrm{N}=20.0$ & 11 & 979.9306 & 89.0846 & 3286.609 & & \\
\hline $\mathrm{C} / \mathrm{N}=21.1$ & 11 & 1023.803 & 93.07296 & 2818.605 & & \\
\hline $\mathrm{C} / \mathrm{N}=22.6$ & 11 & 1051.351 & 95.57733 & 7029.023 & & \\
\hline $\mathrm{C} / \mathrm{N}=22.8$ & 11 & 1067.176 & 97.01602 & 1813.93 & & \\
\hline \multicolumn{7}{|l|}{ ANOVA } \\
\hline Source of Variation & SS & $d f$ & MS & $F$ & p-value & F crit \\
\hline Between Groups & 398.3631 & 3 & 132.7877 & 0.035533 & 0.990889 & 2.838745 \\
\hline Within Groups & $149,481.7$ & 40 & 3737.041 & & & \\
\hline Total & 149,880 & 43 & & & & \\
\hline
\end{tabular}


Table A6. One-way (ANOVA) test for methane yield every three days from the first five reactors.

\begin{tabular}{|c|c|c|c|c|c|c|}
\hline $\begin{array}{c}\text { Anova: Single Factor } \\
\text { SUMMARY }\end{array}$ & & & & & & \\
\hline Groups & Count & Sum & Average & Variance & & \\
\hline $\mathrm{C} / \mathrm{N}=20.0$ & 11 & 979.9306 & 89.0846 & 3286.609 & & \\
\hline $\mathrm{C} / \mathrm{N}=21.1$ & 11 & 1023.803 & 93.07296 & 2818.605 & & \\
\hline $\mathrm{C} / \mathrm{N}=22.6$ & 11 & 1051.351 & 95.57733 & 7029.023 & & \\
\hline $\mathrm{C} / \mathrm{N}=22.8$ & 11 & 1067.176 & 97.01602 & 1813.93 & & \\
\hline Ave $C / N=24.2$ & 11 & 1321.423 & 120.1293 & 3433.406 & & \\
\hline \multicolumn{7}{|l|}{ ANOVA } \\
\hline Source of Variation & SS & $d f$ & MS & $F$ & $p$-value & F crit \\
\hline Between Groups & 6550.961 & 4 & 1637.74 & 0.445484 & 0.775136 & 2.557179 \\
\hline Within Groups & $183,815.7$ & 50 & 3676.314 & & & \\
\hline Total & $190,366.7$ & 54 & & & & \\
\hline
\end{tabular}

Table A7. One-way (ANOVA) test for methane yield every three days from the last four reactors.

\begin{tabular}{|c|c|c|c|c|c|c|}
\hline $\begin{array}{c}\text { Anova: Single Factor } \\
\text { SUMMARY }\end{array}$ & & & & & & \\
\hline Groups & Count & Sum & Average & Variance & & \\
\hline $\mathrm{C} / \mathrm{N}=25.1$ & 11 & 1617.179 & 147.0163 & 5369.843 & & \\
\hline $\mathrm{C} / \mathrm{N}=26.5$ & 11 & 1723.404 & 156.6731 & $12,032.22$ & & \\
\hline $\mathrm{C} / \mathrm{N}=27.1$ & 11 & 2007.842 & 182.5311 & $13,639.7$ & & \\
\hline $\mathrm{C} / \mathrm{N}=30.0$ & 11 & 3009.458 & 273.587 & $31,249.45$ & & \\
\hline \multicolumn{7}{|l|}{ ANOVA } \\
\hline Source of Variation & SS & $d f$ & MS & $F$ & $p$-value & F crit \\
\hline Between Groups & $110,009.3$ & 3 & $36,669.78$ & 2.354732 & 0.086381 & 2.838745 \\
\hline Within Groups & $622,912.2$ & 40 & $15,572.8$ & & & \\
\hline Total & $732,921.5$ & 43 & & & & \\
\hline
\end{tabular}

Table A8. One-way (ANOVA) test for methane yield every three days from all reactors.

\begin{tabular}{|c|c|c|c|c|c|c|}
\hline $\begin{array}{c}\text { Anova: Single Factor } \\
\text { SUMMARY }\end{array}$ & & & & & & \\
\hline Groups & Count & Sum & Average & Variance & & \\
\hline $\mathrm{C} / \mathrm{N}=20.0$ & 11 & 979.9306 & 89.0846 & 3286.609 & & \\
\hline $\mathrm{C} / \mathrm{N}=21.1$ & 11 & 1023.803 & 93.07296 & 2818.605 & & \\
\hline $\mathrm{C} / \mathrm{N}=22.6$ & 11 & 1051.351 & 95.57733 & 7029.023 & & \\
\hline $\mathrm{C} / \mathrm{N}=22.8$ & 11 & 1067.176 & 97.01602 & 1813.93 & & \\
\hline Ave $C / N=24.2$ & 11 & 1321.423 & 120.1293 & 3433.406 & & \\
\hline $\mathrm{C} / \mathrm{N}=25.1$ & 11 & 1617.179 & 147.0163 & 5369.843 & & \\
\hline $\mathrm{C} / \mathrm{N}=26.5$ & 11 & 1723.404 & 156.6731 & $12,032.22$ & & \\
\hline $\mathrm{C} / \mathrm{N}=27.1$ & 11 & 2007.842 & 182.5311 & $13,639.7$ & & \\
\hline $\mathrm{C} / \mathrm{N}=30.0$ & 11 & 3009.458 & 273.587 & $31,249.45$ & & \\
\hline \multicolumn{7}{|l|}{ ANOVA } \\
\hline Source of Variation & SS & $d f$ & MS & $F$ & $p$-value & F crit \\
\hline Between Groups & $318,877.3$ & 8 & $39,859.66$ & 4.446814 & 0.000144 & 2.042986 \\
\hline Within Groups & $806,727.9$ & 90 & 8963.643 & & & \\
\hline Total & $1,125,605$ & 98 & & & & \\
\hline
\end{tabular}




\section{References}

1. Baykara, S.Z. Hydrogen: A brief overview on its sources, production and environmental impact. Int. J. Hydrog. Energy 2018, 43, 10605-10614. [CrossRef]

2. Pradhan, P.; Mahajani, S.M.; Arora, A. Production and utilization of fuel pellets from biomass: A review. Fuel Process. Technol. 2018, 181, 215-232. [CrossRef]

3. Alvarado, R.; Ponce, P.; Alvarado, R.; Ponce, K.; Huachizaca, V.; Toledo, E. Sustainable and non-sustainable energy and output in Latin America: A cointegration and causality approach with panel data. Energy Strategy Rev. 2019, 26, 100369. [CrossRef]

4. Zhang, Q.; Hu, J.; Lee, D.-J.; Chang, Y.; Lee, Y.-J. Sludge treatment: Current research trends. Bioresour. Technol. 2017, $243,1159-1172$. [CrossRef]

5. Obi, F.; Ugwuishiwu, B.; Nwakaire, J. Agricultural waste concept, generation, utilization and management. Niger. J. Technol. 2016, 35, 957-964. [CrossRef]

6. Mymrin, V.; Pedroso, D.E.; Pedroso, C.; Alekseev, K.; Avanci, M.A.; Winter, E., Jr.; Cechin, L.; Rolim, P.H.; Iarozinski, A.; Catai, R.E. Environmentally clean composites with hazardous aluminum anodizing sludge, concrete waste, and lime production waste. J. Clean. Prod. 2018, 174, 380-388. [CrossRef]

7. El-Mashad, H.M.; Zhang, R. Biogas production from co-digestion of dairy manure and food waste. Bioresour. Technol. 2010, 101, 4021-4028. [CrossRef]

8. Pubule, J.; Blumberga, A.; Romagnoli, F.; Blumberga, D. Finding an optimal solution for biowaste management in the Baltic States. J. Clean. Prod. 2015, 88, 214-223. [CrossRef]

9. Katinas, V.; Marčiukaitis, M.; Perednis, E.; Dzenajavičienè, E.F. Analysis of biodegradable waste use for energy generation in Lithuania. Renew. Sustain. Energy Rev. 2019, 101, 559-567. [CrossRef]

10. Oladejo, J.; Shi, K.; Luo, X.; Yang, G.; Wu, T. A review of sludge-to-energy recovery methods. Energies 2019, 12, 60. [CrossRef]

11. Đurđević, D.; Blecich, P.; Lenić, K. Energy potential of digestate produced by anaerobic digestion in biogas power plants: The case study of Croatia. Environ. Eng. Sci. 2018, 35, 1286-1293. [CrossRef]

12. Ülgüdür, N.; Ergüder, T.H.; Uludağ-Demirer, S.; Demirer, G.N. High-rate anaerobic treatment of digestate using fixed film reactors. Environ. Pollut. 2019, 252, 1622-1632. [CrossRef]

13. Álvarez, J.; Otero, L.; Lema, J. A methodology for optimising feed composition for anaerobic co-digestion of agro-industrial wastes. Bioresour. Technol. 2010, 101, 1153-1158. [CrossRef]

14. Archer, S.A.; Steinberger-Wilckens, R. Systematic analysis of biomass derived fuels for fuel cells. Int. J. Hydrog. Energy 2018, 43, 23178-23192. [CrossRef]

15. Xu, R.; Zhang, K.; Liu, P.; Khan, A.; Xiong, J.; Tian, F.; Li, X. A critical review on the interaction of substrate nutrient balance and microbial community structure and function in anaerobic co-digestion. Bioresour. Technol. 2018, 247, 1119-1127. [CrossRef]

16. Fagerström, A.; Al Seadi, T.; Rasi, S.; Briseid, T. The Role of Anaerobic Digestion and Biogas in the Circular Economy; IEA Bioenergy: Paris, France, 2018.

17. Kankia, M.U.; Baloo, L.; Mohammed, B.S.; Hassan, S.B.; Haruna, S.; Danlami, N.; Ishak, E.A.; Samahani, W.N. Effects of petroleum sludge ash in fly ash-based geopolymer mortar. Constr. Build. Mater. 2021, 272, 121939. [CrossRef]

18. Jagaba, A.H.; Shuaibu, A.; Umaru, I.; Musa, S.; Lawal, I.M.; Abubakar, S. Stabilization of soft soil by incinerated sewage sludge ash from municipal wastewater treatment plant for engineering construction. Sustain. Struct. Mater. Int. J. $2019,2,32-44$.

19. Gerardi, M.H. The Microbiology of Anaerobic Digesters; John Wiley \& Sons: Hoboken, NJ, USA, 2003.

20. Sathish, S.; Balaji, R.; Shafee, S.; Mageswaran, C. Experimental Analysis on Anaerobic Digestion of Industrial Waste Biomass. AIP Conf. Proc. 2020, 2225, 060002.

21. Sun, J.; Sun, X.; Sun, R.; Su, Y. Fractional extraction and structural characterization of sugarcane bagasse hemicelluloses. Carbohydr. Polym. 2004, 56, 195-204. [CrossRef]

22. Sun, Y.; Cheng, J. Hydrolysis of lignocellulosic materials for ethanol production: A review. Bioresour. Technol. 2002, 83, 1-11. [CrossRef]

23. Kumar, R.; Mago, G.; Balan, V.; Wyman, C.E. Physical and chemical characterizations of corn stover and poplar solids resulting from leading pretreatment technologies. Bioresour. Technol. 2009, 100, 3948-3962. [CrossRef]

24. Ravindran, R.; Jaiswal, A.K. A comprehensive review on pre-treatment strategy for lignocellulosic food industry waste: Challenges and opportunities. Bioresour. Technol. 2016, 199, 92-102. [CrossRef]

25. Agbor, V.B.; Cicek, N.; Sparling, R.; Berlin, A.; Levin, D.B. Biomass pretreatment: Fundamentals toward application. Biotechnol. Adv. 2011, 29, 675-685. [CrossRef]

26. Fernandes, T.; Bos, G.K.; Zeeman, G.; Sanders, J.; Van Lier, J. Effects of thermo-chemical pre-treatment on anaerobic biodegradability and hydrolysis of lignocellulosic biomass. Bioresour. Technol. 2009, 100, 2575-2579. [CrossRef]

27. Chen, G.; Zheng, Z.; Luo, Y.; Zou, X.; Fang, C. Effect of alkaline treatment on anaerobic digestion of rice straw. Huan Jing Ke Xue Huanjing Kexue 2010, 31, 2208-2213.

28. Carrère, H.; Dumas, C.; Battimelli, A.; Batstone, D.; Delgenès, J.; Steyer, J.; Ferrer, I. Pretreatment methods to improve sludge anaerobic degradability: A review. J. Hazard. Mater. 2010, 183, 1-15. [CrossRef]

29. Xu, Y.; Lu, Y.; Zheng, L.; Wang, Z.; Dai, X. Perspective on enhancing the anaerobic digestion of waste activated sludge. J. Hazard. Mater. 2020, 389, 121847. [CrossRef] 
30. Mao, C.; Feng, Y.; Wang, X.; Ren, G. Review on research achievements of biogas from anaerobic digestion. Renew. Sustain. Energy Rev. 2015, 45, 540-555. [CrossRef]

31. AZIM, K.; OUYIHYA, K.; AMELLOUK, A.; PERISSOL, C.; THAMI ALAMI, I.; SOUDI, B. Dynamic composting optimization through $\mathrm{C} / \mathrm{N}$ ratio variation as a startup parameter. Build. Org. Bridges 2014, 3, 787-790.

32. Ghaleb, A.A.S.; Kutty, S.R.M.; Ho, Y.-C.; Jagaba, A.H.; Noor, A.; Al-Sabaeei, A.M.; Almahbashi, N.M.Y. Response Surface Methodology to Optimize Methane Production from Mesophilic Anaerobic Co-Digestion of Oily-Biological Sludge and Sugarcane Bagasse. Sustainability 2020, 12, 2116. [CrossRef]

33. Council, N.R. Methane Generation from Human, Animal, and Agricultural Wastes: Report of an Ad Hoc Panel of the Advisory Committee on Technology Innovation, Board on Science and Technology for International Development, Commission on International Relations, National Research Council; National Academies: Washington, DC, USA, 1977; Volume 276.

34. Ghaleb, A.; Kutty, S.; Ho, Y.; Jagaba, A.; Noor, A.; Al-Sabaeei, A.; Kumar, V.; Saeed, A. Anaerobic Co-Digestion for Oily-Biological Sludge with Sugarcane Bagasse for Biogas Production under Mesophilic Condition. In Proceedings of the IOP Conference Series: Materials Science and Engineering, Kuala Lumpur, Malaysia, 9-11 August 2020; p. 012084.

35. Szymczycha-Madeja, A.; Welna, M.; Zyrnicki, W. Multi-element analysis, bioavailability and fractionation of herbal tea products. J. Braz. Chem. Soc. 2013, 24, 777-787. [CrossRef]

36. Sun, X.; Xu, F.; Sun, R.; Fowler, P.; Baird, M. Characteristics of degraded cellulose obtained from steam-exploded wheat straw. Carbohydr. Res. 2005, 340, 97-106. [CrossRef] [PubMed]

37. Reddy, K.O.; Shukla, M.; Maheswari, C.U.; Rajulu, A.V. Mechanical and physical characterization of sodium hydroxide treated Borassus fruit fibers. J. For. Res. 2012, 23, 667-674. [CrossRef]

38. Pandey, K. A study of chemical structure of soft and hardwood and wood polymers by FTIR spectroscopy. J. Appl. Polym. Sci. 1999, 71, 1969-1975. [CrossRef]

39. Rao, P.S.; Reddy, K.S.; Kalyani, S.; Krishnaiah, A. Comparative sorption of copper and nickel from aqueous solutions by natural neem (Azadirachta indica) sawdust and acid treated sawdust. Wood Sci. Technol. 2007, 41, 427-442.

40. Liu, D.; Han, G.; Huang, J.; Zhang, Y. Composition and structure study of natural Nelumbo nucifera fiber. Carbohydr. Polym. 2009, 75, 39-43. [CrossRef]

41. Zhang, Z.; Rackemann, D.W.; Doherty, W.O.; O'Hara, I.M. Glycerol carbonate as green solvent for pretreatment of sugarcane bagasse. Biotechnol. Biofuels 2013, 6, 153. [CrossRef]

42. Ray, D.; Sarkar, B. Characterization of alkali-treated jute fibers for physical and mechanical properties. J. Appl. Polym. Sci. 2001, 80, 1013-1020. [CrossRef]

43. Mwaikambo, L.Y.; Ansell, M.P. Chemical modification of hemp, sisal, jute, and kapok fibers by alkalization. J. Appl. Polym. Sci. 2002, 84, 2222-2234. [CrossRef]

44. Lehmann, J.; Joseph, S. Biochar for environmental management: An introduction. In Biochar for Environmental Management; Routledge: London, UK, 2015; pp. 33-46.

45. Karatzos, S.K.; Edye, L.A.; Doherty, W.O.S. Sugarcane bagasse pretreatment using three imidazolium-based ionic liquids; mass balances and enzyme kinetics. Biotechnol. Biofuels 2012, 5, 62. [CrossRef]

46. Liu, L.; Sun, J.; Li, M.; Wang, S.; Pei, H.; Zhang, J. Enhanced enzymatic hydrolysis and structural features of corn stover by FeCl3 pretreatment. Bioresour. Technol. 2009, 100, 5853-5858. [CrossRef]

47. Lee, H.; Hamid, S.; Zain, S. Conversion of lignocellulosic biomass to nanocellulose: Structure and chemical process. Sci. World J. 2014, 2014, 631013. [CrossRef]

48. Torres, M.L.; Lloréns, M.d.C.E. Effect of alkaline pretreatment on anaerobic digestion of solid wastes. Waste Manag. 2008, 28, 2229-2234. [CrossRef]

49. Lin, Y.; Wang, D.; Wu, S.; Wang, C. Alkali pretreatment enhances biogas production in the anaerobic digestion of pulp and paper sludge. J. Hazard. Mater. 2009, 170, 366-373. [CrossRef]

50. Grady, C.L., Jr.; Daigger, G.T.; Love, N.G.; Filipe, C.D. Biological Wastewater Treatment; CRC Press: Boca Raton, FL, USA, 2011.

51. Fang, H.H.; Liu, H. Effect of $\mathrm{pH}$ on hydrogen production from glucose by a mixed culture. Bioresour. Technol. 2002, 82, 87-93. [CrossRef]

52. Verma, S. Anaerobic digestion of biodegradable organics in municipal solid wastes. Columbia Univ. 2002, 7, 98-104.

53. Yen, H.-W.; Brune, D.E. Anaerobic co-digestion of algal sludge and waste paper to produce methane. Bioresour. Technol. 2007, 98, 130-134. [CrossRef]

54. Murto, M.; Björnsson, L.; Mattiasson, B. Impact of food industrial waste on anaerobic co-digestion of sewage sludge and pig manure. J. Environ. Manag. 2004, 70, 101-107. [CrossRef]

55. Procházka, J.; Dolejš, P.; Máca, J.; Dohányos, M. Stability and inhibition of anaerobic processes caused by insufficiency or excess of ammonia nitrogen. Appl. Microbiol. Biotechnol. 2012, 93, 439-447. [CrossRef]

56. Marchaim, U.; Krause, C. Propionic to acetic acid ratios in overloaded anaerobic digestion. Bioresour. Technol. 1993, 43, 195-203. [CrossRef]

57. Wang, X.; Yang, G.; Feng, Y.; Ren, G.; Han, X. Optimizing feeding composition and carbon-nitrogen ratios for improved methane yield during anaerobic co-digestion of dairy, chicken manure and wheat straw. Bioresour. Technol. 2012, 120, 78-83. [CrossRef]

58. Kainthola, J.; Kalamdhad, A.S.; Goud, V.V. Optimization of process parameters for accelerated methane yield from anaerobic co-digestion of rice straw and food waste. Renew. Energy 2020, 149, 1352-1359. [CrossRef] 
59. Kainthola, J.; Kalamdhad, A.S.; Goud, V.V. Enhanced methane production from anaerobic co-digestion of rice straw and hydrilla verticillata and its kinetic analysis. Biomass Bioenergy 2019, 125, 8-16. [CrossRef]

60. Stuckey, D.C.; McCarty, P.L. The effect of thermal pretreatment on the anaerobic biodegradability and toxicity of waste activated sludge. Water Res. 1984, 18, 1343-1353. [CrossRef]

61. Vlyssides, A.; Karlis, P. Thermal-alkaline solubilization of waste activated sludge as a pre-treatment stage for anaerobic digestion. Bioresour. Technol. 2004, 91, 201-206. [CrossRef]

62. Oosterhuis, M.; Ringoot, D.; Hendriks, A.; Roeleveld, P. Thermal hydrolysis of waste activated sludge at Hengelo wastewater treatment plant, The Netherlands. Water Sci. Technol. 2014, 70, 1-7. [CrossRef]

63. Costa, A.G.; Pinheiro, G.C.; Pinheiro, F.G.C.; Dos Santos, A.; Santaella, S.T.; Leitão, R.C. The use of thermochemical pretreatments to improve the anaerobic biodegradability and biochemical methane potential of the sugarcane bagasse. Chem. Eng. J. 2014, 248, 363-372. [CrossRef]

64. Alagöz, B.A.; Yenigün, O.; Erdinçler, A. Enhancement of anaerobic digestion efficiency of wastewater sludge and olive waste: Synergistic effect of co-digestion and ultrasonic/microwave sludge pre-treatment. Waste Manag. 2015, 46, 182-188. [CrossRef] [PubMed]

65. Maragkaki, A.; Fountoulakis, M.; Gypakis, A.; Kyriakou, A.; Lasaridi, K.; Manios, T. Pilot-scale anaerobic co-digestion of sewage sludge with agro-industrial by-products for increased biogas production of existing digesters at wastewater treatment plants. Waste Manag. 2017, 59, 362-370. [CrossRef]

66. Mehryar, E.; Ding, W.; Hemmat, A.; Talha, Z.; Hassan, M.; Mamat, T.; Hei, K. Anaerobic co-digestion of oil refinery wastewater with bagasse; evaluating and modeling by neural network algorithms and mathematical equations. BioResources 2017, 12, 7325-7340.

67. Alagöz, B.A.; Yenigün, O.; Erdinçler, A. Ultrasound assisted biogas production from co-digestion of wastewater sludges and agricultural wastes: Comparison with microwave pre-treatment. Ultrason. Sonochem. 2018, 40, 193-200. [CrossRef] [PubMed] 